\title{
IT and Beyond: The Contribution of Heterogeneous Capital to Productivity
}

\author{
Daniel J. Wilson \\ Federal Reserve Bank of San Francisco
}

May 2007

Working Paper 2004-13

http://www.frbsf.org/publications/economics/papers/2004/wp04-13bk.pdf

\begin{abstract}
The views in this paper are solely the responsibility of the authors and should not be interpreted as reflecting the views of the Federal Reserve Bank of San Francisco or the Board of Governors of the Federal Reserve System. This paper was produced under the auspices for the Center for the Study of Innovation and Productivity within the Economic Research Department of the Federal Reserve Bank of San Francisco.
\end{abstract}




\title{
IT and Beyond: The Contribution of Heterogeneous Capital to Productivity
}

\author{
Daniel Wilson (Federal Reserve Bank of San Francisco) ${ }^{1}$
}

Draft: May 2007

\footnotetext{
${ }^{1}$ Economist, Federal Reserve Bank of San Francisco, 101 Market St., MS 1130, San Francisco, CA 94105; (415) 974-3423 (office), (415) 974-2168 (fax); Daniel.Wilson@sf.frb.org (email). Geoffrey MacDonald provided superb research assistance. I thank Ron Jarmin and Kristen McCue of the Center for Economic Studies for providing the ACES-Compustat bridge file and Larry Rosenblum for providing the data on BLS rental prices. This paper benefitted from helpful comments from Sandy Black, Mark Doms, John Fernald, Simon Gilchrist, John Haltiwanger, Bart Hobijn, Kevin Stiroh, two anonymous referees, and seminar participants at FRBSF, CES, and the NBER Summer Institute. The research in this paper was conducted while the author was a research associate at the CES and California Census Research Data Center (CCRDC); special thanks go to Ritch Milby of the CCRDC. Research results and conclusions expressed are those of the author and do not necessarily indicate concurrence by the Bureau of the Census, the CES, or the Federal Reserve System. This paper has been screened to ensure that no confidential data are revealed.
} 


\begin{abstract}
This paper explores the relationship between capital composition and productivity using a unique and highly detailed data set on firm-level investment in the U.S. We develop a succinct methodology for modeling the separate effects of a large number of capital types in a production function framework. We then use this methodology, combined with recently developed techniques for accounting for unobserved productivity, to identify these effects and back out the implied marginal products of each capital type. The results indicate that information and communications technology (ICT) capital - specifically, computers, software, and communications equipment - are positively and statistically significantly associated with output, even after conditioning on total capital, labor, and various proxies for unobserved productivity. We compare the implied marginal products for different capital types to official data on rental prices and find that the marginal products of the ICT capital types are substantially above their measured rental prices. Lastly, we provide evidence of complementarities and substitutabilities, both among capital types - a rejection of the common assumption of perfect substitutability - and between certain capital types and labor. [Keywords: Capital Heterogeneity, Productivity, Investment, Production Function Estimation; JEL Codes D21, D24, D29.]
\end{abstract}




\section{Introduction}

There has been a tremendous amount of public interest and debate in the last several years on how information and communication technologies (ICT) affect productivity. A number of studies have found that ICT investment is associated with higher labor productivity even after controlling for ICT's contribution to capital deepening. This leads one to ask: Is ICT special? That is, does investment in ICT equipment have a greater impact on productivity than investment in other capital goods? Are there other specific capital goods that contribute to productivity in disproportion to their share of capital? More generally, does the mix of capital affect productivity? This paper seeks to answer these questions.

Understanding how ICT interacts with other capital goods in production is of fundamental importance to understanding the nature of the production function. It is also particularly relevant for understanding the sources of the rapid rise in aggregate TFP over the last decade, a period in which the mix of physical capital in the economy has changed dramatically. Beyond the specific issue of the ICT-productivity link, previous research has not empirically examined the relationship between the entire capital mix and productivity. This paper is able to do so by making use of the microlevel data from a unique, highly detailed survey of U.S. businesses, the 1998 Annual Capital Expenditures Survey (ACES).

The special focus on ICT up until now is understandable given its increasingly vital role in business and personal activity. However, there are several reasons to expand our attention beyond the productivity impact of ICT to the impact of other capital goods as well, and, in fact, to expand our attention to the impact of the capital mix more generally. First, computers, software, and communications equipment are not purchased in isolation. They are often purchased in conjunction with other capital goods to build a system of capital to accomplish productivity enhancements. ${ }^{1}$ Thus, even if one's interest is only in the productivity impact of ICT, one must account for its correlation with other specific capital goods that have their own impact on productivity. Second, policymakers considering incentives such as investment tax credits and accelerated depreciation allowances aimed at increasing productivity need

\footnotetext{
${ }^{1}$ Wilson [2004], in fact, using the full 1998 ACES sample of nearly 30,000 firms, provides evidence of exactly that. Specifically, Wilson finds that the share of Computers in total firm investment is positively correlated with the investment shares of Other Office Equipment, Software, Furniture, Office Buildings, Commercial Buildings, and several other types of capital.
} 
to know which capital asset types should be targetted (i.e., just ICT or other capital goods as well). ${ }^{2}$ For this purpose, one must know the productivity impacts of every type of capital. Third, nearly all micro-level production studies are forced, given data limitations, to assume a single, homogenous capital stock (two at most). In reality, capital is clearly heterogeneous. The potential measurement error arising from this assumption has long been recognized (e.g., Solow [1955-56], Fisher [1965], and Jorgenson and Griliches [1967]), but the data necessary to address this concern has not previously been available at the micro-level.

The goal of this paper is to begin to fill in the gap in our understanding of the relationship between capital mix and productivity. The paper offers four main contributions. First, we construct a unique new firm-level data set, combining data on asset-specific investment with data on output and factor inputs (among other variables), that allows one to investigate the contribution of heterogenous capital to output and productivity. Specifically, we match firm observations from the Census Bureau's recent Annual Capital Expenditures Survey (ACES) of 1998, which contains investment broken out across a wide range of separate capital types, to the Compustat research file, which contains data on output and factor inputs (in 1998 as well as subsequent years) for publicly-traded firms. As is frequently the case with large-scale survey data, the ACES reflects a tradeoff between data richness (i.e., how much detail is requested of respondents) and the frequency of the survey. Thus, it is important to acknowledge at the outset that the tremendous richness of these data, in terms of providing quite disaggregate investment for a large cross-section of firms, comes at the cost of having no time dimension. This precludes the use of panel data econometric techniques for addressing endogeneity concerns, though we use a number of other approaches to address these concerns.

The second contribution of the paper is to develop a succinct methodology for modeling the separate effects of a large number of capital types in a production function framework. We show that, under relatively mild conditions, these effects can be estimated via linear regression analysis using data on investment mix along with total capital stock and other factor inputs. Our third contribution is to use this methodology, combined with recently developed techniques for accounting for unob-

\footnotetext{
${ }^{2}$ See House and Shapiro (2006) for a discussion of the effects of the temporary accelerated depreciation allowances enacted in the U.S. in 2002 and 2003, which differentially favored long-lived capital types.
} 
served productivity, to identify the effects of different types of capital on output and to back out the implied marginal products of different types of capital. Our baseline regression results clearly indicate that investment in computers, communications equipment, software, and offices are positively associated with both current and subsequent years' output, conditional on total capital and labor. We perform a number of exercises to determine the primary direction of causality explaining these correlations. We find these results are robust to including either a one year lead of the firm's Solow Residual or a polynomial of investment, capital, and age ( a la Olley and Pakes [1996]) in the regressions - both of which are techniques for directly controlling for unobserved productivity. However, including a proxy for organizational capital wipes out the offices-productivity association while leaving the association for the ICT capital types, suggesting ICT capital has a causal effect on output even after controlling for the effects of total capital and labor.

We then back out the marginal products of different capital types implied by our regression results and compare these to data on rental prices provided by the BLS. For the most part, the implied marginal products are strikingly similar to these rental price estimates, as would be predicted by standard Neoclassical theory. However, for a few key types like computers, communications equipment, and software, the implied marginal products are found to be substantially higher than the official rental prices. The implied excess returns to ICT capital suggest differential adjustment costs among capital types, unobserved complementary co-investments with ICT capital, or systematic expectational errors by firms regarding the relative marginal products of different capital goods.

Our fourth contribution is to test for production complementarities and substitutabilities among capital goods, and between different types of capital and labor. We find strong evidence of such complementarities and substitutabilities. In particular, using any reasonable division of types into "high-tech" and "low-tech" categories, the data indicate that high-tech capital goods tend to be complementary with low-tech capital goods and substitutable with other high-tech capital. Not only does this result have interesting implications for productivity, it also is a rejection of the assumption that capital goods are perfectly substitutable, an assumption researchers are often forced to make in the empirical micro productivity literature. We also find complementarities and substitubilities between certain capital types and labor. For instance, software is found to be especially labor-saving, while general purpose machinery and 
trucks are especially labor-augmenting. Given the well-documented shifts in aggregate capital composition in the U.S. over the last decade or so, this result may have implications for trends in labor demand and relative wages.

The organization of the paper is as follows: Section 2 discusses the previous literature investigating the relationship between ICT investment, or the capital mix more broadly, and productivity. Section 3 derives the empirical model that we estimate and discusses the econometric issues that arise. The data that we use are summarized in Section 4. Section 5 describes the main results, where capital type investment shares are not interacted with each other or labor. Section 6 describes the results of adding these interactions to investigate complementarities and substitutabilities among capital types and between capital types and labor. Section 7 concludes.

\section{Background}

As mentioned at the start of the paper, up to this point the literature on the productivity impact of disaggregate investment has focused almost exclusively on computers and communications equipment (and mostly just computers). ${ }^{3}$ The macroeconomic literature typically has relied on growth accounting exercises to explore the issue, while microeconomic studies generally have relied on firm- or establishment-level production function estimation, with ICT capital as a separate production input in addition to labor and non-ICT capital. ${ }^{4}$

During the 1980s and the first half of the 1990s, most studies found little or no evidence of an economically important contribution of IT or ICT on productivity or productivity growth. Examples include Oliner and Sichel [1994], Griliches and Siegel [1992], and Berndt and Morrison [1995]. Berndt and Morrison [1995], in fact, found that IT capital's share of total capital services was negatively related to TFP in panel fixed-effects regressions using data on 2-digit manufacturing industries from 1968-1986.

More recently, a consensus appears to be forming that IT and ICT investment

\footnotetext{
${ }^{3}$ An exception is Caselli and Wilson [2004], which used country-level data on capital imports to explore the determinants of capital composition and its effects on labor productivity.

${ }^{4}$ On the macro side, see Oliner and Sichel [1994,2000], Jorgenson and Stiroh [2000], and Gordon [2000]. On the micro side, see Brynjolfsson and Hitt [1996, 2003]; Lehr and Lichtenberg [1999]; Greenan and Mairesse [2000]; Gilchrist, Gurbuxani, and Town [2003], and Hempell [2005]. For similar analyses at the industry-level, see Berndt and Morrison [1995]; Gera, Gu, and Lee [1999]; and Stiroh [2002].
} 
are positively associated with conventionally-measured total factor productivity, although the magnitude, direction of causality, and timing of this association is still very much under debate. ${ }^{5}$ Oliner and Sichel [2000] used growth accounting techniques to identify the contribution, within a standard Neoclassical production framework, of IT capital to aggregate productivity growth. They found that the use and production of IT equipment together account for two-thirds of the acceleration in productivity growth that occurred between the first half and the second half of the 1990s. ${ }^{6}$

On the micro side, Brynjolfsson and Hitt [1995, 1996] estimate that the returns to IT spending are substantially higher than those to non-IT spending. Greenan and Mairesse [2000] find evidence that computer use has a positive impact on productivity at the firm level using data on the French manufacturing and services sectors. However, they cannot reject the hypothesis that computer's contribution to productivity is the same as the contribution of other capital. Gilchrist, Gurbaxani, and Town [2003] use a modified version of the Arellano and Bond [1991] GMM estimator to estimate the elasticity of the IT capital stock via both a production function and a multi-factor productivity (MFP) framework. They find that IT's elasticity in the production function is about equal to its cost share and is not significant in the MFP regression (both consistent with normal returns within the Neoclassical model). However, they also find that personal computers (PCs) have an impact on productivity above and beyond their contribution to the IT stock. They find these excess returns are limited to the durable goods sector; PCs have no impact on MFP in the nondurables sector. Brynjolfsson and Hitt [2003] estimate the elasticity of computers using both shortand long-difference regressions. They find that computers' elasticity is consistent with their cost share in the short differences; but, consistent with Gilchrist, et al., the long difference results suggest excess returns, as the computers' elasticity is significantly higher than computers' cost share.

While these and other studies in the productivity literature up until now have generally focused exclusively on computers (and, to a lesser extent, communications equipment), the investment literature has explored the implications of capital heterogeneity more broadly for adjustment costs (e.g., Hayashi and Inoue [1991] and Chirinko

\footnotetext{
${ }^{5}$ The issues of this debate are discussed in Stiroh [forthcoming], which performs a meta-analysis of the literature on estimating the elasticity of output with respect to IT capital. He shows that estimates of this elasticity are sensitive to the time period and industry coverage of the data, the model specification, and the econometric technique.

${ }^{6}$ Jorgenson and Stiroh [2000] obtained similar results, also using a growth accounting framework.
} 
[1993]) and tax policy (Goolsbee [2004]; Cummins, Hassett, and Hubbard [1994]; and House and Shapiro [2006]). Most relevant to this paper, Cummins and Dey [1998] estimate a structural model in which heterogeneous capital goods are allowed to differentially affect production and adjustment technologies and find important effects of imperfect substitutability. Their capital stock data, however, is only broken down into two groups: equipment and structures.

\section{Empirical Model}

The focus of this paper is on the relationship between heterogeneous capital services and labor productivity at the firm level. The goal of this section is to derive an empirical, firm-level production function specification incorporating heterogeneous capital services based on standard Neoclassical production theory. This theory, dating back to Solow [1955-56], contends that the services of heterogeneous capital goods can be expressed as a single aggregate quantity, $X=g\left(X^{0}, X^{1}, \ldots, X^{N}\right)$, if the marginal rate of substitution between any two capital goods is independent of the quantity of labor. The production function for a firm (or the economy as a whole) can then be treated as a function of labor and this single capital aggregate.

Unfortunately, the appropriate aggregator function $g()$ is unknown. Fisher (1965) demonstrated that if different types (or vintages) of capital embody different levels of quality, i.e., they have different marginal products, then there is an additional necessary and sufficient condition for the existence of a single capital aggregate: the heterogeneous quality must be expressible in homogenous constant-quality units - this is the well-known "better = more" assumption. This condition along with the weak separability with labor are equivalent to requiring that different capital types be perfect substitutes once they have been measured in constant-quality units. A firm's total capital services then can be expressed as a sum of individual capital services weighting each by its relative marginal product.

It is important to distinguish this exercise of measuring the quantity of total capital services with the far more common exercise, done in growth accounting studies, of measuring the change in total capital services. The goal in growth accounting is to attribute the change in output (for a firm, industry, or economy) into the change in inputs, including capital services, and the change in TFP. As Jorgenson and Griliches [1967] and others have shown, when one is only seeking to measure the change in 
total capital services and not the actual quantity, one need not make the restrictive assumptions discussed above. (In particular, perfect substitutability between different capital goods is not required.) Rather, a Divisia index (e.g., Tornqvist) of total capital services can be constructed from observed changes in the quantities of individual capital services. ${ }^{7}$ Of course, as an index number, this index provides no information about the actual level of capital services, only its current level relative to past levels. Hence, it is of no use in measuring the true quantity of capital services entering a firm's production function, which is what one needs in order to estimate production parameters using cross-firm regression analysis.

Assuming the Solow-Fisher conditions hold ${ }^{8}$, a firm $i$ has total capital services, $X_{i}$, equal to the weighted sum of individual capital services: $X_{i}=\sum_{j=0}^{N}\left(1+\theta_{j}\right) X_{j i}$, where $j$ indexes capital types and $\left(1+\theta_{j}\right)$ are weights that sum to one across capital types. $^{9} \quad$ If we make the further assumption that each individual capital service is proportional to the firm's stock of capital of that type (i.e., utilization rates do not vary across types), then $X_{j i}=b K_{j i}$ and $X_{i}=b \sum_{j=0}^{N}\left(1+\theta_{j}\right) K_{j i}$, where $K_{j i}$ is the stock of capital of type $j$. Thus, total capital services is a weighted sum of individual capital stocks. The role of the weights, $\left(1+\theta_{j}\right)$, is to convert whatever units $K_{j i}$ is measured in into constant-quality units that can be compared across types. By setting $\theta_{0}=0$, we choose the units of capital type 0 as the basis of measurement for all goods. As shown below, the weights represent the marginal products of each capital type relative to the marginal product of the base type. In the data used in this paper, the units of capital type 0 are dollars (book value). Hence, the weights in the capital services summation can be thought of as converting the dollar value of each capital type

${ }^{7}$ The Divisia index is defined by:

$$
\frac{\dot{X}}{X}=\sum w^{j}\left(\frac{\dot{X}^{j}}{X^{j}}\right),
$$

where $X_{j}$ is the $j$ th capital service and $w^{j}$ is the value of the $j$ th capital service as a share of the value of total capital services. In the Tornqvist index, $w^{j}$ is an average of this share in $t$ and $t+1$.

${ }^{8}$ In section 6 , we relax the assumption of perfect substitutability among capital goods and instead allow the marginal product of capital type $j$ to depend on the quantity of each other capital type.

${ }^{9}$ Though Jorgenson and Griliches [1967] (and subsequent growth accounting studies like Jorgenson and Stiroh [2000]) focus on a Divisia index to measure the change in total capital services, they do in fact use an arithmetic sum, as we do, to measure the level of the capital services for subgroups of capital goods. Like we do, they also point out that the key to aggregating goods within a group is that the units of each good be converted to a common base by using their relative marginal products. 
into its equivalent dollar value in terms of the base capital type, using their relative marginal products for the conversion.

For example, suppose a firm has a stock of computers and a stock of tractors with equal market values. As we know from Hall and Jorgenson's (1967) work on the user cost of capital, even though the market values of these two capital stocks are equal, the flow of capital services they provide, and hence their marginal products, may be very different. For instance, a higher marginal product of computers may be offset by a higher rate of depreciation, leaving the return to computers equal to the return to tractors. If the marginal product of tractors were our base of measurement, then an appropriate measure of the total flow of capital services for this firm would be proportional to (with factor of proportionality $b$ ) the stock of tractors plus the product of the stock of computers and the ratio of the marginal product of computers to the marginal product of tractors.

Now let us define the production function for output. We assume a standard Cobb-Douglas production function in terms of capital services $\left(X_{i}\right)$ and labor $\left(L_{i}\right)$ with a Hicks-neutral technology shift parameter $\left(A_{i}\right): Y_{i}=A_{i} F\left(X_{i}, L_{i}\right)=A_{i} X_{i}^{\alpha} L_{i}^{\beta}$. Plugging in our expression for $X_{i}$ (and $\theta_{0}=0$ ) into the production function, we get:

$$
\begin{aligned}
Y_{i} & =A_{i}\left[\sum_{j=0}^{N}\left[\left(1+\theta_{j}\right) K_{i j}\right]\right]^{\alpha} L_{i}^{\beta} ; \theta_{0}=0 \\
& =A_{i}\left[1+\sum_{j=1}^{N} \theta_{j} \frac{K_{i j}}{K_{i}}\right]^{\alpha} K_{i}^{\alpha} L_{i}^{\beta}
\end{aligned}
$$

where $K_{i}=\sum_{j=0}^{N} K_{i j} ; j$ indexes capital types: $p=0,1, \ldots, N-1$, where $N$ is the number of types. $K_{i j}$ is the book value of the $j$ th capital stock, measured in current dollars and $K_{i}$ is the total book value of capital. It is straightforward to verify that $\left(1+\theta_{j}\right)$ is the ratio of the marginal product of type $j$ capital to that of the base type:

$$
\frac{\partial Y}{\partial K_{j}} / \frac{\partial Y}{\partial K_{0}} \equiv F_{j} / F_{0}=1+\theta_{j}
$$

Thus, $\theta_{j}$ represents the percentage difference between capital type $j$ 's marginal product and the marginal product of the numeraire capital type. In the standard Neoclassical model, optimizing firms choose the quantity of each input such that its marginal product is equal to its implicit rental price (user cost), in which case the input is said to be earning normal returns. The ratio between the marginal products 
of different capital stocks is then equal to the ratio of their user costs (see Jorgenson [1963]). Thus, the standard Neoclassical model would predict that $1+\theta_{j}=\left(c_{j} / c_{0}\right)$, where $c_{j}$ and $c_{0}$ are the user costs for type- $j$ and type-0 capital, respectively.

There are a number of possible reasons, however, that $1+\theta_{j}=\left(c_{j} / c_{0}\right)$ might not hold. First, there could be adjustment costs and/or learning-by-doing processes that differentially affect capital goods. For instance, Cummins and Dey [1998] estimated that adjustment costs for equipment capital are significantly different (lower, in general) than for structures capital, suggesting that differences likely exist among types within these broad categories as well. In addition, a number of studies have analyzed recent and historical episodes wherein productivity was adversely affected in the short-run by learning costs involved with the introduction of either new types of capital goods to existing production processes or pre-existing capital goods to new applications (e.g., see David's [1990] study of computers in the 1960s through 1980s and the electric dynamo at the turn of the last century). Second, there may be unobserved organizational co-investments, such as new workplace practices and management systems, associated with particular capital goods (e.g., see Bresnahan and Greenstein [1996]; Black and Lynch [2001]; Brynjolfsson, Hitt, and Yang [2002]; Bresnahan, Brynjolfsson, and Hitt [2002]; and Bartel, Ichniowski, and Shaw [2004a] regarding links between recent changes in management techniques and information technology capital). Third, due to uncertainty regarding the rate of return on capital investments, there could be systematic expectational errors by firms that may be more severe for certain capital goods, particularly new and/or rapidly changing capital goods. Of course, these three possible causes of non-normal returns are not mutually exclusive. For example, errors in expected productivity gains from particular capital investments may be related to unexpectedly high learning/adjustment costs or to unanticipated needs for additional investments in organizational capital.

The principal focus of the empirical analyses in this paper is on obtaining consistent estimates of the set of $\theta_{j}$ s, i.e., the coefficients on the capital shares. To estimate the $\theta_{j}$ s via linear regression, the production function must first be linearized. If $\sum_{j=1} \theta_{j} \frac{K_{i j}}{K_{i}} \approx 0$ (recall $\sum_{j=1} \theta_{j}=0$ ), then, to an approximation, the production function in logs becomes ${ }^{10}$ :

\footnotetext{
${ }^{10}$ Any approximation error introduced here is likely to result in a negative bias in OLS estimation of the $\theta_{j}$ s. For simplicity, consider the case where there is only one capital type $(j=1)$ in addition to the numeraire type. As $\theta_{1} \xi_{1}$ diverges from zero, the approximation error, $\log \left(1+\theta_{1} \xi_{1}\right)-\theta_{1} \xi_{1}$,
} 


$$
\ln \left(Y_{i t}\right)=a_{i t}+\alpha \ln \left(K_{i t}\right)+\beta \ln \left(L_{i t}\right)+\sum_{j=1} \alpha \theta_{j} \frac{K_{i j t}}{K_{i t}},
$$

where $a_{i t}=\ln \left(A_{i t}\right)$ and we have now explicitly added time subscripts. ${ }^{11}$ This equation forms the basis for the primary regression specification we use to investigate the association between individual capital types and output conditional on total capital and labor.

As noted in the introduction, an important limitation of the 1998 ACES data is that it contains disaggregate investment, but not disaggregate capital stocks. Hence, capital shares $K_{i j t} / K_{i t}$ are unobserved. Investment shares $I_{i j t} / I_{i t}$, however, are observed, and with the proper data, capital shares can be approximated from investment shares. From the standard capital accumulation equations, $I_{i j t}=\triangle K_{i j, t+1}+\delta_{j} K_{i j t}$ and $I_{i t}=\triangle K_{i, t+1}+\delta K_{i, t}$, one gets:

$$
\frac{K_{i j t}}{K_{i t}}=\frac{\left(g_{i, t+1}+\delta\right)}{\left(g_{i j, t+1}+\delta_{j}\right)} \cdot \frac{I_{i j t}}{I_{i t}}
$$

where $g_{i j, t+1}=\triangle K_{i j, t+1} / K_{j i, t}$ and $g_{i, t+1}=\triangle K_{i, t+1} / K_{i, t}$ are the growth rates of capital type $j$ and total capital, respectively. Unfortunately, these growth rates of capital are unobserved in the data. If the growth rates are small (relative to the depreciation rates), as would be expected in a steady state, the first term in the product above is approximately equal to the ratio of total depreciation to type- $j$ depreciation. ${ }^{1213}$ Above, we showed that $\theta_{j}$ represents the relative marginal product of type- $j$ capital which is an omitted variable in the estimation, will become increasingly negative. So if the true $\theta_{1}$ is nonzero, then the omitted variable will be more negative for firms with larger shares of investment in type $1\left(\xi_{1}\right)$. Hence, there will be a negative bias on the estimator of $\theta_{1}$. In particular, notice that any findings of excess returns that we obtain are likely to be underestimates whereas findings of below-normal returns may be overstated.

${ }^{11}$ A similar formulation, containing a weighted sum of disaggregate capital shares in addition to total capital, was employed in the empirical studies of Berndt and Morrison (1995) and Lehr and Lichtenberg (1999), though to a much more limited extent. The former disaggregated capital into office equipment, other equipment, and structures; the latter broke capital into IT and non-IT capital.

${ }^{12}$ Lehr and Lichtenberg (1999), in their study of the returns to computer capital, similarly approximated capital shares using the product of investment shares and this ratio of depreciation rates.

${ }^{13}$ To the extent that firms deviate from balanced growth, the bias (on the estimator of $\theta_{j}$ ) caused by omitting the difference between the capital share and the investment share in a regression is likely to be negative. The reason goes as follows: Type-specific investment is likely to be lumpy over time, so a high (conditional on industry and other regressors), type- $j$ investment share this period generally signals a low beginning-of-period type- $j$ capital stock share. Thus, the partial correlation between 
(minus one). Using investment shares in lieu of capital shares in our regressions thus changes the interpretation of $\theta_{j}$ from $\left[\left(F_{j} / F_{0}\right)-1\right]($ eq. $(2))$ to $\left[\left(F_{j} / F_{0}\right)-1\right]\left(\delta / \delta_{j}\right)$. Likewise, we showed above that the Neoclassical prior (based on firms choosing factor quantities until marginal products equal rental prices) for this parameter is $\left(c_{j} / c_{0}\right)-1$. Using investment shares, this prior becomes $\left[\left(c_{j} / c_{0}\right)-1\right]\left(\delta / \delta_{j}\right)$. In section 5.2 , we back out the marginal products implied by our estimated $\hat{\theta}_{j}$ s and compare them to the widely-used user cost estimates generated by the Bureau of Labor Statistics (BLS).

Returning to the specifications discussed above, the shift variable, $a_{i t}$, is an unobserved variable that is likely to vary by firm and may possibly be correlated with the other regressors. To formalize this possibility let us rewrite $a_{i t}$ as:

$$
a_{i t}=m_{i t}+v_{i t}
$$

The first term, $m_{i t}$, is the component of productivity that is known, or "transmitted," to the firm when it makes its variable input decisions, but it is unobserved by the econometrician. This term encompasses both time-invariant and time-varying productivity factors (that are known to the firm). The second term, $v_{i t}$, is a productivity innovation that is ex-ante unknown even to the firm. It is orthogonal to all factor inputs including the capital mix. The concern with estimating equation (3) via OLS is that transmitted productivity, $m_{i t}$, may be correlated with the firm's input decisions, including the capital composition decision, leading the OLS estimator of our parameters to be biased.

One often can control at least for the time-invariant aspects of $m_{i t}$, i.e., firm fixed effects, through panel data methods (e.g., first-differencing). In this paper, however, we have only a single cross-section of data, for 1998, on $K_{j i t} / K_{i t}$ (though data for subsequent years is available for the variables $Y_{i t}, K_{i t}$, and $\left.L_{i t}\right)$. Due to this limitation of the data, our identification strategy is to focus on the cross-sectional estimation and include potential proxies or correlates of both the time-varying and time-invariant aspects of $m_{i t}$.

$\left.\overline{I_{i j} / I_{i} \text { and the omitted variable }\left(K_{i j} / K_{i}\right.}-I_{i j} / I_{i}\right)$ is negative, which implies a negative bias on the estimator of the investment share's coefficient $\left(\alpha \theta_{j}\right)$. In particular, significantly positive estimates of $\alpha \theta_{j}$, such as those we obtain for Computers, Software, and Communications Equipment, cannot be explained by omitted variable bias. 
At a minimum, one can attempt to account for $m_{i t}$ with a set of control variables:

$$
\ln \left(Y_{i, 98}\right)=c+\alpha \ln \left(K_{i, 98}\right)+\beta \ln \left(L_{i, 98}\right)+\sum_{j=1} \alpha \theta_{j} \frac{I_{j i, 98}}{I_{i, 98}}+\Psi(\text { Control Variables })+\epsilon_{i, 98}
$$

We will refer to this equation as our baseline regression. The first set of control variables are meant to capture permanent firm characteristics. These consist of 3-digit SIC level industry dummy variables, location (state) dummies, and a 5-category indicator of firm size (employment); this size variable is described in Appendix A. The state (of headquarters) dummy is included because a number of studies have found that location has an important effect on firm performance; this effect can be due, for example, to networks/technological spillovers or density (see, e.g., Audretsch and Feldman [1996], Ciccone and Hall [1996], and Ellison and Glaeser [1999]). We also include a dummy variable indicating whether the firm had an investment spike (investment equally $20 \%$ or more of the beginning-of-year book value of capital, which is a common spike definition in the literature (e.g., Doms and Dunne [1998])). The investment spike dummy is included because firms with a spike may incur high short-run adjustment costs resulting in lower output, ceteris paribus. Conversely, the spike may reflect the firm's response to a positive productivity shock (similar to how investment is argued to reflect unobserved productivity shocks in Olley and Pakes [1996]). Either way, it should be included in the regression since investment spikes may consist disproportionately of certain capital goods, thus excluding the spike variable could bias the coefficients on the investment shares of those capital goods.

Since it is unlikely the transmitted productivity term, $m_{i t}$, will be fully captured by these control variables alone, we investigate three alternative approaches which build on the baseline regression above. The first approach follows the Olley and Pakes (1996) technique. Olley and Pakes show that under certain conditions - notably perfect competition and the exogeneity of $m_{i t}$ with respect to the firm's variable input decisions - current investment will be a monotonic function of $m_{i t}$, the capital stock, and age. The monotonicity of this unknown function implies that $m_{i t}$ will be a function of investment, capital, and age. They suggest proxying for this unknown function using a kernel estimator or a polynomial. We follow this approach using a 3rd-order polynomial (including interaction terms). In our particular context, the validity of the Olley-Pakes approach requires one additional condition: the transmitted productivity shock should affect total investment demand, but not the composition of investment (i.e., it must not disproportionately affect the demand for some capital types relative 
to others). ${ }^{14}$.

The second approach is to include a measure of one-year-ahead Solow Residual as an additional regressor (relative to the baseline regression). The Solow Residual is defined as $s r d_{i t}=\ln \left(Y_{i t}\right)-s_{i t}^{K} \ln \left(K_{i t}\right)-s_{i t}^{L} \ln \left(L_{i t}\right)$, where $s_{i t}^{K}$ and $s_{i t}^{L}$ are the observed factor shares of capital and labor, respectively (see Appendix A for how these shares were measured). Note that even though capital shares are only observed in our data for 1998, the components of the Solow Residual (which come from Compustat) are observed in other years as well. From equations (3) (substituting capital shares for investment shares) and (5), we get:

$$
\ln \left(Y_{i, 99}\right)=m_{i, 99}+v_{i, 99}+\alpha \ln \left(K_{i, 99}\right)+\beta \ln \left(L_{i, 99}\right)+\sum_{j=1} \alpha \theta_{j} \frac{I_{i j, 99}}{I_{i, 99}}
$$

which implies:

$$
\operatorname{srd}_{i, 99}=m_{i, 99}+v_{i, 99}+\left(\alpha-s_{i}^{K}\right) \ln \left(K_{i, 99}\right)+\left(\beta-s_{i}^{L}\right) \ln \left(L_{i, 99}\right)+\sum_{j=1} \alpha \theta_{j} \frac{I_{j i, 99}}{I_{i, 99}} .
$$

Note that the unobserved, transmitted productivity term, $m_{i, 99}$, can be decomposed into a time-invariant fixed effect, $f_{i}$, and a component specific to $1999, \omega_{i, 99}$, and recall that $v_{i, 99}$ is an i.i.d. productivity innovation (which is uncorrelated with the 1998 productivity innovation, $v_{i, 98}$ ). Thus, as one can see from the expression for $s r d_{i, 99}$ above, adding $\operatorname{srd}_{i, 99}$ as an additional regressor to the baseline regression should control for the fixed effect, $f_{i}$, as well as the transmitted productivity shock $\omega_{i, 98}$ to the extent that $\omega_{i, t}$ follows an $\operatorname{AR}(1)$ process (since $\omega_{i, 99}=\rho \omega_{i, 98}+\varepsilon_{i, 99}$, where $\varepsilon_{i, 99}$ is i.i.d.). Thus, under the joint hypothesis that the production model is correctly specified and $\omega_{i t}$ is $\operatorname{AR}(1)$, the residual of this regression, $\epsilon_{i, 98}$, should correctly identify the true i.i.d. productivity innovation, $v_{i, 98}$. In other words, this equation can be consistently estimated via OLS. Note, however, that this regression will certainly not produce an efficient estimation. There may be serious multicollinearity from having both the 1998 investment shares and $s r d_{i, 99}$, which is affected by the 1999 investment shares, as regressors. This multicollinearity will bias upward the standard errors on

\footnotetext{
${ }^{14}$ We can get some sense of the validity of this condition by comparing the estimated coefficients on the capital-type investment shares from a regression in which the investment shares are lagged oneyear (i.e., all variables are 1999 values except the 1998 investment shares), and hence pre-determined, to those from a regression with all contemporaneous (1998) values. We do so in Section 5 and find that the coefficients are quite similar.
} 
the estimates of $\alpha \theta_{j}$. The standard errors on the capital and labor elasticities also may be upward biased to the extent that the true elasticities differ from observed factor shares. Again, though, the bias in the standard errors can be seen as a virtue in that they reduce the likelihood of a false finding of statistical significance on the investment share coefficients. Therefore, this regression provides a useful check on the consistency of the baseline results.

Lev and Radhakrishnan (2005), among others, have argued that firm-level organizational capital can be proxied by a firm's selling, general, and administrative (SGA) expenses. SGA (by Compustat's definition) includes advertising/marketing expenses, amortization of research and development costs, cost of engineering services, leasing costs, and freight costs. These types of costs can be thought of as investments in the firm's knowledge base, brand reputation, and distribution capacity, which collectively comprise its "organizational capital." Both the time-invariant and time-varying components of the unobserved, transmitted productivity term $\left(m_{i t}\right)$ are likely to be strongly correlated with organizational capital, and hence SGA. Therefore, our fourth approach is to include (log) SGA as an additional regressor in equation (6) to control for unobserved, transmitted productivity.

In all regressions, we measure output using firm sales deflated by a 3-digit industry price deflator corresponding to the firm's predominant industry. ${ }^{15}$ As is common in the literature ${ }^{16}$, we exclude intermediate expenses (materials) as the CobbDouglas portion of the production function and thus the estimating equation. This exclusion amounts to assuming that the gross output $\left(G O_{i t}\right)$ production function is Leontief (weakly separable) in value added $\left(Y_{i t}\right)$ and materials $\left(M_{i t}\right)$ :

$$
G O_{i t}=\min \left(Y_{i t}, M_{i t}\right)
$$

\footnotetext{
${ }^{15} \mathrm{As}$ is standard in the empirical literature on productivity and production function estimation (see, e.g., Dunne, et al. [2004]), we use a gross output concept for output instead of value added. Properly measuring real value added requires separate price deflators, which generally are not available, for materials costs and gross output. Moreover, even if deflators were available, double-deflated value added has been shown to be a biased measure of real value added in the presence of imperfect competition (Basu \& Fernald [1999]).

${ }^{16}$ Examples in the micro literature include Bahk and Gort [1993] and Lev and Radhakrishnan [2005]. On the macro side, Basu [1996]; Burnside, Eichenbaum, and Rebelo [1995]; and Basu and Fernald [1999], among others, have argued that production is approximately Leontief in value added and materials.
} 
Since this production function implies $\ln \left(G O_{i t}\right)=\ln \left(Y_{i t}\right)$, one can estimate equation (3) by simply replacing $\ln \left(Y_{i t}\right)$, which is not observed in the data without substantial measurement error, with $\ln \left(G O_{i t}\right)$, which is observed in the data.

Another option is to assume that the gross output production function is CobbDouglas in capital, labor, and materials and then include $\ln \left(M_{i t}\right)$ as an additional regressor. There are a couple of reasons, however, why omitting materials is preferable. First, including materials would limit our sample size considerably since Compustat does not contain intermediate expenses for a number of companies. More importantly, intermediate expenses in Compustat are subject to a serious measurement error that is likely correlated with capital composition. A large share of certain types of investment, particularly software, communications equipment, and instruments, may be expensed by companies rather than capitalized and therefore reported as intermediate expenses rather than capital investment. Given that the unobserved, omitted measurement error corresponding to observed $\ln \left(M_{i t}\right)$ is correlated with the capital-type investment shares (some positively, some negatively), the OLS estimator will provide inconsistent estimates of the $\alpha \theta_{j} \mathrm{~s}$ if $\ln \left(M_{i t}\right)$ is included in the regression. ${ }^{17}$ Nonetheless, in addition to results from the baseline specification excluding materials, we also report results below from adding (log) materials to the specification (6). The implied $\theta_{j}$ s are generally unaffected (we discuss below the handful of types that are affected).

\section{Data}

\subsection{The Regression Sample}

The principal sources of data for this paper are the 1998 Annual Capital Expenditures Survey (ACES) and Compustat. ${ }^{18}$ The ACES is conducted annually by the U.S. Census Bureau to elicit information on capital expenditures by U.S. private, nonfarm companies. The information is used by the BEA in constructing the National Income

\footnotetext{
${ }^{17}$ Another, more practical, problem with including intermediate expenses as part of the regression equation is that selling, general, and administrative expenses (SGA), which we use as a proxy for organization capital, is included in intermediate expenses. Thus, the effect of organization capital cannot be separately identified in a regression including intermediate expenses.

${ }^{18}$ For more details regarding the 1998 Annual Capital Expenditures Survey, including the published aggregate data and the actual survey questionaires, see Census Bureau (2000).
} 
and Product Accounts (NIPA). ${ }^{19}$

In typical years, the ACES queries companies on their expenditures on total equipment and total structures, in addition to related values such as total book value of capital assets, accumulated depreciation, and retirements. In the 1998 survey, however, the ACES additionally required firms to report their investment broken down by 55 separate types of capital - 26 types of equipment and 29 types of structures. A list of these types is given in Appendix B. The 1998 ACES is unique as the only large-scale, micro-level survey of investment in the U.S. that disaggregates investment into a full range of detailed asset types (i.e., beyond simply total equipment and total structures, and beyond just one or two asset types such as computers or transportation equipment). These data on disaggregate investment allow us to observe the complete composition of firms' investment, which is the focus of this paper.

The 1998 ACES sampling frame consists of all U.S. private, nonfarm employers. All companies with 500 or more employees were surveyed while smaller employers were surveyed based on a stratified random sampling such that larger firms were sampled with a higher probability. Response to the ACES is legally required so response rates are extremely high. In the end, responses were obtained from nearly 34,000 firms, with around 28,000 reporting some positive investment.

Unfortunately, aside from sales, book value of total capital assets, and detailed investment, the ACES does not collect information on other key variables needed for productivity analysis. Most importantly, ACES does not record employment levels. To obtain data on these other variables, we match the ACES data to the Compustat research file. ${ }^{20}$ The drawback of this merger is that Compustat only covers publiclytraded companies, which are a small subset of the firms in ACES (as in the overall economy), albeit a subset of very large firms that account for a large share of U.S. economic activity. ${ }^{21}$ Matching ACES to Compustat, and dropping observations from

\footnotetext{
${ }^{19}$ The ACES is the primary source of data used by the BEA to construct estimates of aggregate equipment and structures investment for non-manufacturing industries. As described below, the 1998 ACES collected data on investment by detailed asset type; this information is now being used by the BEA in constructing its Capital Flows Tables and its Fixed Reproducible Tangible Wealth estimates, but only in a very limited way. See Becker, Haltiwanger, Jarmin, Klimek, and Wilson (2004) for more on this issue.

${ }^{20} \mathrm{~A}$ bridge file linking Compustat's unique firm identifier, CUSIP, with the unique firm identifier in the ACES was generously provided (and constructed) by Ron Jarmin and Kristen McCue of the Center for Economic Studies, U.S. Census Bureau.

${ }^{21}$ Another, more minor, drawback of the Compustat data in this context is that Compustat data
} 
firms with missing values in Compustat for one or more of the variables in equation (6) above, yielded a sample of 1,651 firms.

\subsection{Investment Patterns and Summary Statistics}

Before getting into the analysis of the relationship between the composition of capital (across types) and productivity residuals, it is useful to consider the relevant patterns that have been found regarding disaggregate investment behavior at the micro-level as well as the basic characteristics of our sample. Wilson (2004) uses the full 1998 ACES sample, with around 28,000 firms, to establish a number of interesting stylized facts about firms' investment behavior in terms of heterogeneous capital. Two of those findings are of particular relevance here.

First, Wilson finds that a given firm's investment tends to be concentrated in a small number of capital types, though what these types are varies greatly from firm to firm. This is particularly true for structures capital: $72 \%$ of the firms that reported having some structures investment did so in only a single structure type (only $11 \%$ had investment in three or more types) ${ }^{22}$; yet no single structure type averages more than $20 \%$ of total structures for these firms. Equipment investment tends to be less concentrated, with $55 \%$ of equipment-buying firms having investment in three or more equipment types. These statistics imply that for many types of capital, especially structure types, investment is a rather uncommon phenomenon, which suggests that identifying the relationship between these types of investment and labor productivity will be exceedingly difficult. Fortunately, however, for both equipment and structures, investment diversity tends to increase with firm size. In particular, among firms at or above the 90th percentile of sales - a group which roughly corresponds to the Compustat sample - over $70 \%$ invested in three or more types of equipment, $25 \%$ invested in three or more types of structures. Nonetheless, to further reduce the frequency of zeros in the investment shares, and hence increase the shares'

on sales, labor, capital book value, and materials costs are global, while the investment data in ACES is U.S. only. In the empirical exercises below, we assume that the domestic investment shares from ACES are a reasonable proxy for global investment shares. This should be a valid assumption given that in the ACES-Compustat merged sample, the ratio of ACES fixed assets and Compustat fixed assets is near one for most of the sample (with a median of 0.924 , a 25th percentile of 0.725 , and a 75 th percentile of 0.999$)$.

${ }^{22} 39 \%$ of the firms in ACES had at least some structures investment; $78 \%$ had some equipment investment. 
cross-sectional variability, we partially aggregate the 55 ACES type categories up to 20 types. $^{23}$ The mapping from the original 55 ACES categories to the 20 categories used in this paper is shown in Appendix B.

The second finding from Wilson (2004) of particular relevance here is that capital goods vary greatly in terms of how widely used they are among industries. Of the 55 capital types shown in Appendix B, Computers are the most widely used, followed by Software. ${ }^{24}$ For instance, using the sample weights in the ACES to get an appropriate economy-wide estimate, the top four Computer-investing industries accounted for only $24 \%$ of all Computer investment in 1998. For Software, this "top-4 industry concentration ratio" was just $26 \%{ }^{25}$ Such pervasiveness of use across a wide range of industries has been identified as a defining characteristic of so-called "general purpose technologies" (Bresnahan and Trajtenberg, 1995). Other widely purchased capital goods were "Other Office Equipment" and "Manufacturing, Processing, and Assembly Plants." Conversely, many other capital goods, especially structure types, are extremely concentrated in just a few industries (with top- 4 industry concentration ratios above $90 \%$ ).

These findings affect the interpretation of the coefficients on the type-specific investment shares in our regressions. The regressions contain 3-digit SIC industry dummies, but if a capital good tends to be highly concentrated, what we may be identifying with its share coefficient is actually an industry effect below the 3 -digit level. In the description below of the regression results, the focus is generally on the "general purpose" capital goods such as Computers, Software, Instruments, Fabricated Metal Products, etc.. Other asset categories, particularly structures, are predominately industry-specific asset types. Their inclusion in these regressions serves more to control for industry effects not accounted for by the 3-digit SIC industry dummies.

Now, let us turn briefly to the basic characteristics of our regression sample. Table 1 provides summary statistics for the main variables used in the analysis below. One can see here that the firms in this sample are indeed quite large. Sales among

\footnotetext{
${ }^{23}$ In addition, as a robustness check on the main regression results reported below, we tried excluding firms which reported investment in fewer than 3 capital types (at the 20-type level). This had virtually no effect on the regression results, as this restriction excluded very few firms from our sample.

${ }^{24}$ Throughout the paper, capital type names are capitalized to indicate that they refer to specific categories of capital listed in Appendix B.

${ }^{25}$ Somewhat surprisingly, Communications Equipment turned out to be rather concentrated, with an industry concentration ratio of $87 \%$.
} 
these firms averaged roughly $\$ 2.3$ billion in 1998 and they employed an average of 12,447 workers. These firms collectively accounted about $28 \%$ of gross output and $19 \%$ of employment in the U.S. private nonfarm economy. ${ }^{26}$ While this sample of firms clearly represents a large fraction of economic activity in the U.S., it should be noted that the empirical results presented below can only be said to reflect the population of large firms; the relationship between capital composition and productivity for smallto medium-sized firms could well be different.

The average firm in our sample invested in 5 different types of equipment and 2 different types of structures. On average, sample firms spent $15 \%$ of their total capital expenditures on Computers, $16 \%$ on Special Industry Machinery, $11 \%$ on Miscellaneous Equipment, and less than $10 \%$ on each other capital type. The lowest average investment share is $1 \%$ (for Trucks). Interestingly, firms in the sample reported much less investment, on average, on Software and Communications Equipment, each with about $3 \%$ of total investment, than on Computers. ${ }^{27}$

It is also worth noting the raw correlations between sales and each of the variables in our regressions. These are shown in the last column of Table 1. Interestingly, Computers have virtually no correlation with sales and Software is actually negatively correlated with sales, even though, as shown below, these capital types are positively associated with sales in a multivariate production function regression analysis.

\footnotetext{
${ }^{26}$ The sales figures here are based on the Compustat Net Sales variable (\#A12). Total sales for the sample was $\$ 3.871$ trillion and total employment was 20.588 million. According to the BEA's gross output by industry data, private nonfarm gross output in 1998 was $\$ 13.961$ trillion. Total private nonfarm employment in 1998 was 106.021 million (from BLS Earnings and Employment).

${ }^{27}$ This contrasts with National Income and Product Accounts (NIPA) data which shows Software investment in 1998 was actually slightly greater than Computer investment. The difference likely comes from how ACES and NIPA treat expensed software. In the ACES, firms are instructed to report investment in software "only if capitalized as part of a tangible asset" and to exclude it "if the purchase is considered intangible (e.g., licensing agreement) or if expensed such as office supplies." The NIPAs, on the other hand, classify all software expenditures as investment regardless of whether the firm accounts for the expenditures as capital or intermediate expenses. (Note that software that is bundled with, or embedded in, hardware is not counted as software investment in either ACES or NIPAs.)
} 


\section{Results}

\subsection{Full Sample Results}

Table 2 presents the main results of the cross-sectional regressions described in Section 3. Each regression is estimated via Ordinary Least Squares; standard errors (shown in parentheses in the Table) are computed using the heteroskedasiticity-consistent (HuberWhite) variance-covariance matrix. All variables, except where otherwise noted, are 1998 values. We also experimented with using 1999 values instead, while still using 1998 investment shares, as a further attempt to mitigate the possible simultaneous response of investment shares to contemporaneous productivity shocks in 1999. This would be appropriate if the true capital accumulation process were such that there is a one year lag between when investment takes place and when capital actually is put into use. The 1999 results are quite similar to the 1998 results shown in Table 2 and are provided in Appendix B.

As the production model in Section 3 suggests, it is necessary to choose a numeraire capital type whose $\theta_{j}$ is zero by definition. We choose Special Industry Machinery and omit its investment share from the regression. The choice of numeraire type is arbitrary and innocuous; it in no way affects the relative marginal products, i.e., the sum or difference of any two $\theta_{j} \mathrm{~s} .{ }^{28}$ However, the point estimate and statistical significance of each $\theta_{j}$ applies specifically to the $j$ th investment share relative to the particular investment share that is omitted. In the following section, we will back out the actual marginal products of each type, which are not affected by the choice of numeraire.

Before considering the results, a few words regarding the interpretation of these regressions are warranted. The statistical associations that these regressions identify are those between the investment shares and output conditional on labor and book value of capital (and other control variables). Given that the conventional measure of total- or multi-factor productivity is output net of capital quantity (measured either by book value or perpetual inventory accumulation) and labor, each weighted by their production elasticities, these regressions also identify the associations between the investment shares and conventionally measured multi-factor productivity. However, since this conventional multi-factor productivity (MFP) omits the potential additional

\footnotetext{
${ }^{28}$ We have verified this by repeating these regressions using alternative capital types as the omitted category.
} 
factor of capital composition/quality, we caution against interpreting the investment share coefficients as associations with true total factor productivity (TFP). The validity of interpreting any statistical associations identified in these regressions as causal effects depend on the extent to which unobserved productivity $\left(m_{i}\right)$ is controlled for.

Column (1) of Table 2 shows the results from estimating equation (6) above. We first note that the baseline regression yields an estimate of the elasticity of output with respect to labor of $0.53(0.04)$ and the elasticity of output with respect to capital stock of 0.42 (0.02). These elasticity estimates are roughly in line with priors based on U.S. aggregate factor shares which are about two-thirds for labor and one-third for capital, though the estimate of labor's elasticity is somewhat below that implied by factor shares while capital's elasticity estimate is somewhat above. In addition, the elasticity estimates suggest approximately constant returns to scale $(\hat{\alpha}+\hat{\beta}=0.95$, which is insignificantly different from one). The coefficient on the investment spike variable is positive but insignificant. Firm size, as proxied by employment size, has no significant relationship with productivity in these regression, all else equal (which is not surprising given that $\log \left(L_{i}\right)$ is already included in the regression).

Turning to the key parameters of interest - the estimated coefficients on the type-specific investment shares - the baseline results show that investment in Computers, Communications Equipment, Software, and Offices is statistically significantly associated, above the $99 \%$ level, with output conditional on labor and book value of capital. The computer coefficient is 0.54 (s.e. $=0.10)$, suggesting that an increase in the computer investment share by 10 percentage points (relative to the omitted capital type) would be expected to be associated with roughly $5 \%$ higher output (conditional on total capital stock and labor). The coefficients on Communications Equipment and Software are somewhat higher at $0.70(0.26)$ and $0.81(0.19)$, respectively. Office Building investment has a coefficient of 0.57 (0.15).

Column (2) shows the results of additionally including (log) materials as a regressor. Note first that, with the exception of just four capital types, the estimated coefficients on the investment shares move closer to zero. This is to be expected. Recall that, in terms of the production function model, the coefficients on the investment shares correspond to $\alpha \theta_{j}$. The inclusion of materials reduces $\hat{\alpha}$ by a factor of 3 (from 0.42 to 0.13$)$. Thus, the coefficients on the investment shares should fall by the same proportion. The implied $\theta_{j} \mathrm{~s}$ from this regression are, in fact, quite similar to those from the first regression, aside from a few statistically insignificant exceptions (Air- 
craft, Fabricated Metal Products, Instruments, Metalworking Machinery, and Other Transportation Eqp.). The coefficients on the investment shares for Computers, Software, and Offices remain positive and statistically significant. Investment in Autos and Industrial Buildings becomes positive and significant, and investment in Other Transportation Equipment becomes significantly negative. Investment in Communications Equipment goes from being strongly statistically significant to only marginally significant, with a $p$-value of 0.12 . It is worth noting the substantial drop in the coefficients on Software and Office Equipment, the two capital types likely to be the most severely affected by the measurement error associated with misreporting of capital expenditures as intermediate expenses. The inclusion of intermediate expenses is likely leading to a misattribution of some of the output contribution of these types to intermediate expenses. It is also worth noting that one obtains very similar results if one replaces 1998 values, for all variables except the investment shares, with 1999 values (see Appendix C). The only notable difference in the 1999 results is that Communications Equipment becomes strongly statistically significant (positively) and the previous significantly negative effect of Other Transportation Equipment goes away. ${ }^{29}$

The regression underlying Column (3) is identical to that of Column (1) except that the terms (including interactions) of a 3rd-order polynomial in total investment $\left(\ln \left(I_{i, 98}\right)\right)$, book value of capital $\left(\ln \left(K_{i, 98}\right)\right)$, and firm age are included as a proxy for unobserved productivity shocks, following Olley and Pakes (1996). Note that in this regression, the coefficient on $\ln (K)$ no longer identifies the capital elasticity and hence is not shown. ${ }^{30}$ The addition of this polynomial has very little effect on the results relative to Column (1). The coefficients on the investment shares for Computers, Software, and Offices are approximately the same and remain highly statistically significant. The coefficient on Communications Equipment falls noticeably (from 0.70 to 0.52 ), though the decline is not statistically significant and the coefficient remains statistically significantly different from zero. It is worth noting that estimating this

\footnotetext{
${ }^{29} \mathrm{It}$ is worth noting here that the estimated factor elasticities from this regression are as expected. If the true gross output production function is $Y=A K^{\tilde{\alpha}} L^{\tilde{\beta}} M^{\tilde{\gamma}}$ and markets are perfectly competitive, the elasticities should be approximately equal to the corresponding shares of capital, labor, and materials in nominal gross output, which, based on U.S. aggregate data, are roughly $0.17,0.33$, and 0.50 , respectively.

${ }^{30}$ Olley and Pakes (1996) show how the capital elasticity can be estimated via a second stage regression. We do not perform the second stage regression here as our primary objective is not to obtain an estimate of the capital elasticity.
} 
regression using 1999 values for all variables except the 1998 investment shares yields very similar results (see Appendix C) - in particular, the coefficients for Computers, Software, Communications Equipment, and Offices are roughly the same magnitude and are statistically significant. This is notable because, as mentioned in Section 3, one potential concern with applying the Olley-Pakes technique in this context is that it assumes firms do not change their investment mix in response to the transmitted productivity shock. If this were not the case, the contemporaneous investment shares, unlike the predetermined, lagged investment shares, would partially reflect the productivity shock, and thus the coefficients on the investment shares would be significantly different when they are lagged versus contemporaneous.

Column (4) presents the results of adding the one-year lead of the Solow Residual $\left(\operatorname{srd}_{i, 99}\right)$ to the baseline regression. Compared with the baseline regression results, this addition has a small but notable effect on the estimated investment share coefficients. Investment in Computers, Software, and Offices remain positively and significantly associated with labor productivity. The coefficient on Communication Equipment falls from 0.70 to 0.42 and is no longer statistically significant at the $10 \%$ level (the $p$ value is 0.12). ${ }^{31}$ We note, though, that when we repeat this regression using 1999 data (except the 1998 investment shares), Communications Equipment is again statistically significant at the $10 \%$ level (with a coefficient of 0.37 (0.20)) (see Appendix C).

In the regression underlying Column (5), we add to the baseline regression the log of selling, general, and administrative expenses (SGA) as a proxy for organizational capital, following Lev and Radhakrishnan (2005). As discussed in Section 3, including SGA as an additional regressor in our main production function regression serves to partially control for the unobserved, transmitted productivity components. Note first that the estimated elasticity of output with respect to organizational capital (SGA) is 0.38. As is to be expected under a prior of approximately constant returns to scale (with labor, physical capital, and organizational capital as production factors), the labor and (physical) capital elasticities fall accordingly, to 0.30 and 0.27 , respectively. The implied returns to scale parameter, at 0.95, is unchanged from the baseline results

\footnotetext{
${ }^{31}$ The estimated standard error on Communications Equipment's investment share in each of these regressions is higher than that of most other capital types. This may be due to the fact that Communications Equipment is not as widely used across industries as are other capital types (recall that in Section 4, we discussed evidence of this from Wilson (2004)). Its investment share is thus equal to zero more often than other types and hence it has less cross-sectional variability which leads to higher standard errors.
} 
(Column (1)).

Given the decline in $\alpha$ of roughly a third, the coefficients on the investment shares should be expected to also decline by about a third relative to the baseline results; and, in general, this appears to be case. Thus, for the most part, the implied relative productivities are unaffected by the inclusion of SGA. The key exception is that the coefficient on Office Buildings falls to near zero and is statistically insignificant. Thus, it appears that the previous statistical association between Office Building investment and output was spurious and driven by the fact that Office Building investment is highly correlated with organizational capital which has a positive effect on labor productivity. ${ }^{32}$ It is worth noting that the coefficients on Computers and Software also fall by more than expected (they each fall by roughly 60\%), though they remain positive and statistically significant. This implies some of the previous association between Computers and Software and productivity likely was due to the fact that these types of capital are important complements with organizational capital which likely has an independent positive effect on conventionally-measured multi-factor productivity.

\subsection{Interpretation of Results}

In section 3 , we showed that the coefficient on a particular investment share, $\alpha \theta_{j}$, can be interpreted as the (ex-post) marginal product of the capital type (relative to the omitted type), adjusted for its relative depreciation rate, times the elasticity of capital in the production function: $\alpha \theta_{j}=\alpha\left[\left(F_{j} / F_{0}\right)-1\right]\left(\delta / \delta_{j}\right)$, where $\delta$ and $\delta_{j}$ are the depreciation rates for total capital and type- $j$ capital, respectively. Under the Neoclassical assumption that firms equilibrate marginal products to factor prices $\left(F_{j} / F_{0}=c_{j} / c_{0}\right)$, this coefficient should thus equal $\alpha\left[\left(c_{j} / c_{0}\right)-1\right]\left(\delta / \delta_{j}\right)$, where $c_{j}$ and $c_{0}$ are the implicit rental prices (also known as user costs) for type- $j$ and type- 0 capital, respectively. The U.S. Bureau of Labor Statistics (BLS) provides estimates of depreciation rates, as well as estimates of rental prices, at a detailed capital type level (which has a many-to-one mapping to our 20-type level). The data are widely used by researchers and other government agencies in the construction of capital stock data. In general, the rental prices are estimated from data on rental rates for specific capital goods observed in

\footnotetext{
${ }^{32}$ Interestingly, the coefficient on Office Equipment, another category one would expect to be highly correlated with organizational capital, also declines considerably, from 0.30 to -0.06 (though the estimator's precision is not sufficient to say the difference is statistically significant).
} 
capital rental markets. The depreciation rates are estimated from prices of used capital assets observed in secondary markets. Using our estimate of $\alpha$, along with the BLS measures of $\delta$ and $\delta_{j}$, one can thus back out the implied ratio of marginal products between capital type $j$ and the numeraire capital type. Further, taking the BLS estimate of the user cost of the numeraire type - in our case, Special Industry Machinery - as approximately equal to the marginal product of this capital type, one can back out the marginal product (per dollar of capital stock) for every capital type.

Table 3 shows the marginal products for each type of capital implied by our regression results. Column (1) shows the rental prices for 1998 provided by the BLS. ${ }^{33}$ Column (2) gives the marginal products implied by the baseline regression results (Column (1) of Table 2), while Column (3) gives the marginal products implied by the regression that controls for organizational capital as proxied by SGA (Column (5) of Table 2). The asterisks next to each implied marginal product indicate the degree to which it is statistically significantly different from the BLS estimated rental price. The confidence intervals here assume that everything in the expression $\alpha\left[\left(F_{j} / F_{0}\right)-1\right]\left(\delta / \delta_{j}\right)$ is known with certainty except the variable of interest, $F_{j}$.

To aid in the comparison, the implied marginal products and BLS rental prices also are shown graphically with the radial chart labeled Figure 1. Each spoke in this chart corresponds to a specific capital type. The points on the spokes that are connected by the solid black lines correspond to the BLS rental prices given in Column (1) of Table 3. The points connected by the dashed black lines correspond to the baseline implied marginal products (Column (2)), while the points connected by the solid gray lines correspond to the implied marginal products shown in Column (3). Stars indicate marginal product estimates that are statistically significantly different from the corresponding BLS rental price.

For most capital types, the marginal product implied by the baseline regression is strikingly similar to the BLS rental price. For instance, for Miscellaneous Equipment, Metalworking Machinery, Instruments, General Purpose Machinery, Fabricated Metal Products, Other Structures, and Aircraft, the difference between the implied marginal product (from the baseline production function estimation) and the BLS rental price is within just three percentage points. For several capital types, however, the implied marginal product is found to be significantly (statistically and economically) higher

\footnotetext{
${ }^{33}$ The BLS actually estimates rental prices by asset type and industry. To arrive at a single rental price estimate for each asset type, we simply average across all industries.
} 
than the BLS estimate of the rental price. In particular, using the baseline production function estimates, Computers are found to have had an ex-post marginal product of $66 \%$ in 1998, compared to the BLS's estimated rental price of $43 \%$. Communications Equipment had an estimated marginal product of $33 \%$, compared to a $16 \%$ estimated rental price. Software also had an estimated marginal product above the BLS's rental price, $119 \%$ vs. $48 \%$.

The baseline implied marginal products for Commercial Buildings, Industrial Buildings, Offices, Utility Structures, and Other Structures are also statistically significantly higher than their BLS rental prices. However, this result should be viewed with caution. First, though statistically significant, the differences for these types are small (ranging from 4-8 percentage points). Second, as noted earlier, structures investment tends to be infrequent and heavily concentrated among industries. Therefore, the estimated coefficients on their investment shares may, to some extent, reflect industry effects not picked up by the 3-digit industry dummies included in the regressions.

The marginal products implied by the regression that includes SGA also is generally quite similar to the BLS rental prices. Looking at Figure 1, the primary differences that stand out are for Communications Equipment, Software, and Autos - with implied marginal products that are substantially above their rental prices and Office Equipment, with an implied marginal product substantially below its rental price. However, only the difference for Communications Equipment is statistically significant.

As discussed in Section 3, there are a number of possible reasons why the estimated ex-post marginal product for a capital good could be different than its rental price. First, there could be adjustment costs, including learning costs, that disproportionately affect particular capital goods (Cummins and Dey [1998], David [1990]). Second, certain capital goods may be associated with unobserved organizational coinvestments. For example, a number of authors have argued that organization coinvestments, such as human resource management (HRM) programs, training programs, quality control systems, etc., contribute to productivity and are facilitated by ICT capital. ${ }^{34}$ Third, due to uncertainty regarding the rate of return on capital investments, there could be systematic expectational errors by firms that may be more severe for certain capital goods. For instance, it is often posited that firms systematically

\footnotetext{
${ }^{34}$ See, e.g., Bresnahan and Greenstein [1996]; Black and Lynch [2001]; Brynjolfsson, Hitt, and Yang [2002]; Bresnahan, Brynjolfsson, and Hitt [2002]; and Bartel, Ichniowski, and Shaw [2004a].
} 
overinvested in Communications Equipment in the late 1990s. Interestingly, though, we find that in fact the marginal product on Communications Equipment during this period was actually above its implicit rental price.

\section{Complementarities and Substitutabilities}

\subsection{Among Capital Types}

The results presented thus far establish that the standard measure of capital stock used in micro-level production functions does not adequately account for capital mix. ${ }^{35}$ But these results do not shed light on the fundamental question of whether it is possible at all to express capital services as a single aggregate. As discussed above in Section 3 , the ability to express a firm's total capital services with a single measure, even if that measure weights heterogeneous capital goods by their relative marginal products, requires that (1) individual capital services each be weakly separable with labor (Solow [1955-56]) and (2) that their services be expressed in common units (Fisher [1965]). ${ }^{36}$ These two conditions together require that different capital services be perfectly substitutible. The hypothesis of perfect substitutability can be straightforwardly tested with the ACES data. 37 Specifically, one can test whether certain "bundles" - i.e., pairs, triples, quadruples, etc., of different types of capital have an impact on output above and beyond the individual effects that each type of capital has. In the case of pairs, this is a test of whether the cross-partial derivative for any pair of capital goods is equal to zero: $F_{j k}=0$ for $j \neq k$.

\footnotetext{
${ }^{35}$ In many studies estimating production functions at the micro level, the capital stock is measured using a perpetual inventory accumulation of past (total) investment flows (i.e., the standard capital accumulation equation, $\left.K_{t}=K_{t-1}(1-\delta)+I_{t}\right)$, rather than by the book value of capital. A number of studies have shown that these two alternative measures of capital stock are extremely highly correlated in the cross section (see, e.g., Becker, et al. [2004]). Thus, using a perpetual inventory measure would not likely change the result that the aggregate capital stock does not adequately account for capital composition in terms of heterogeneous types.

${ }^{36}$ Regarding the first condition, Solow commented it "will not often be even approximately satisfied in the real world."

${ }^{37}$ Denny and May [1978] and Cummins and Dey [1998] similar tested for perfect substitutability between equipment capital and structures capital using industry- and firm-level data, respectively. Both rejected perfect substitutability among these broad asset classes, but neither was able to test the hypothesis within these classes.
} 
Starting with the baseline production function regression discussed above, we add interactions of investment shares between every possible pair (dyad) of capital types in our data. With 20 types, this amounts to 190 interactions. ${ }^{38}$ The results are not shown for space considerations (available from author upon request). We note first that the investment shares for Computers, Communications Equipment, Software, and Office Buildings remain statistically significant, even after the inclusion of these interactions. We find a number of significant interactions, which implies that returns (and marginal products) for particular capital goods are affected by the presence of other complimentary or substitutable capital goods. (An F-test of the hypothesis that all interactions are jointly equal to zero yielded a $p$-value $<0.001$.) This result is a rejection of the perfect substitutability assumption necessary for the existence of a single aggregate measure of capital services.

It is worth highlighting a few of the most notable complementarities and substitutabilities. $^{39}$ Computers and Fabricated Metal Products are found to be complementary, as are Instruments and Fabricated Metal Products. This suggests that traditional, "low-tech" metal products like hand tools, valves, pipes, springs, wires, storage tanks, etc., are made more productive through the use of "high-tech" Computers and Instruments. Instruments are also found to interact positively with Other Transportation Equipment. Other Transportation Equipment, in turn, is found to

\footnotetext{
${ }^{38}$ The number of dyads in a 20 -member set is $(20 \times 19) / 2=190$. In general, the number of $n$-ads in a $G$-member set is $G ! /[n !(G-n) !]$. Using this formula, one can see that adding triad or higher- $n$ interactions, though they may have interesting real effects, would rapidly use up all of the degrees of freedom in our regressions.

${ }^{39}$ The following interactions were found to be significant at the $95 \%$ level or higher (the sign and significance level of their coefficient is in parentheses):

Computers \& Fabricated Metal Products (+, 5\%), Computers \& Commercial Buildings (+, 1\%), Other Office Eqp. \& Aircraft (+, 1\%), Other Office Eqp. \& Misc. Eqp. (-, 5\%), Other Office Eqp. \& Other Structures (-, 1\%), Communications Eqp. \& Industrial Buildings (-, 1\%), Software \& Aircraft (-, 1\%), Software \& Other Transportation Eqp. (+, 5\%), Fabricated Metal Products \& Other Transportation Eqp. (-, 1\%), Fabricated Metal Products \& Instruments (+, 1\%), Fabricated Metal Products \& Commercial Buildings (-, 1\%), Metalworking Machinery \& Autos (-, 1\%), Metalworking Machinery \& Other Transportation Eqp. $(+, 1 \%)$, Autos \& Trucks $(+1 \%)$, Autos \& Elec. Eqp. (-5\%), Other Transportation Eqp. \& Instruments $(+, 5 \%)$, Other Transportation Eqp. \& Misc. Eqp. (+, $5 \%$ ), Misc. Eqp. \& Commercial Buildings (-, 5\%), Commercial Buildings \& Industrial Buildings (+, $5 \%)$, Utility Structures \& Other Structures (+, 5\%), Utility Structures \& Industrial Buildings (+, $1 \%$ ), Office Buildings \& Industrial Buildings (-, 5\%), Special Industry Machinery \& Office Buildings $(+, 5 \%)$.
} 
interact negatively with Fabricated Metal Products. Another finding is that Commercial Buildings are complementary with Computers but substitutable with Fabricated Metal Products.

In general, the findings appear to yield a distinct set of patterns:

(1) "high-tech" capital tends to be complementary with "low-tech" capital,

(2) "high-tech" capital tends to be substitutable with other "high-tech" capital,

(3) "low-tech" capital tends to be substitutable with other "low-tech" capital.

These patterns are true if one groups Computers, Communications Equipment, Software, Instruments, Electrical Equipment, Metalworking Machinery ${ }^{40}, \mathrm{Au}^{-}$ tos, Aerospace, and Special Industry Machinery ${ }^{41}$ into "high-tech" and Other Office Equipment, Fabricated Metal Products, Heavy Duty Trucks, Other Transportation Equipment, Miscellaneous Equipment, and all types of Structures into "low-tech" (with General Purpose Machinery somewhere in between). These classifications are not arbitrary. They would be obtained, almost exactly, if one split the list of capital types on the basis of how much R\&D expenditures are applied to each capital type in the U.S. (See Wilson [2002], who compiled such a list from NSF data). The classifications would also be obtained to a large extent if one split the list according to the implied marginal products (or, for that matter, the official BLS user costs) in Table 3 (exceptions are that Aircraft would become low-tech while Miscellaneous Equipment, Office Equipment, and Office Buildings would become high-tech).

To confirm these patterns more formally, we estimate the same model but restricting the coefficients to be equal within each of the following three groups: (1) pairs of high-tech goods, (2) pairs of low-tech goods, (3) pairs with one high-tech good and one low-tech good (using the high-tech/low-tech classification above ${ }^{42}$ ). Table 4 shows the results of this regression; the first column gives results using 1998 variables, the second gives results using 1999 variables (except for the 1998 investment shares). As expected, interactions within the high-tech/high-tech group are found to be negative

\footnotetext{
${ }^{40}$ For a discussion of recent major innovations in Metalworking Machinery used for valve-making (e.g., Computerized Numerical Control machines), see Bartel, Ichniowski, and Shaw (2004a, 2004b).

${ }^{41}$ As the name suggests, Special Industry Machinery is a hodge-podge of heterogeneous equipment, some of which are better described as "low-tech" (e.g., circular saws) and some of which are better described as "high-tech" (e.g., Semiconductor wafer processing eqp.). Hence, this type could arguably go into either category.

${ }^{42}$ General Purpose Machinery was assigned to the low-tech group for the regressions whose results are shown, though assigning it to high-tech yielded similar results.
} 
(substitutes) on average, as are those within the low-tech/low-tech group, while interactions between high-tech and low-tech goods are found to be positive (complements) on average. The coefficient on the high-tech/high-tech interactions is statistically significantly negative (at the $90 \%$ level or higher) in both yearly regressions and the coefficient on the high-tech/low-tech interactions is statistically significantly positive in both. The coefficient on the low-tech/low-tech interactions is negative but is not statistically significant.

These findings are consistent with the basic intuition that the more similar a pair of goods are, the more substitutable they are. Presumably, high-tech capital goods are more similar to each other than to low-tech goods. On the other hand, a number of authors have argued that high-tech investments such as computers tend to be part of a system of co-investments in complementary goods, some tangible and some intangible (Brynjolfsson, Hitt, and Yang [2002]; Bresnahan, Brynjolfsson, and Hitt [2002]). In particular, one might have expected computers and software to have been found to be complementary. That they are not (though they are not found to be substitutes either) may reflect the fact that computers typically already embody a large amount of software the day they are purchased, hence firms may choose to some extent between buying additional computers with the available pre-loaded software or buying new software for their existing computers. ${ }^{43}$ These two scenarios need not be complementary. A similar argument may apply to the relationship between computers and communications equipment.

In sum, contrary to common perceptions, the data suggest that high-tech capital goods are not in fact complementary with each other, but rather they are complementary with low-tech equipment and structures.

\subsection{Between Capital Types and Labor}

In addition to the complementarities and/or substitutabilities a capital good may have with other capital goods, it may also be complementary or substitutable with labor. In fact, recently, it has often been suggested in the press that one reason U.S. employment growth coming out of the 2001 recession was weak while output and labor productivity growth was strong, unlike in past recessions when employment growth tended to meet or exceed output growth in recoveries, is because the economy increasingly relies on

\footnotetext{
${ }^{43}$ Recall that the software category in ACES, as in the NIPAs, excludes software that is embedded in hardware.
} 
capital technologies that are to some extent substitutes with labor. This argument has particular potency when it comes to explaining weak demand for low-skilled workers, for whom it has been suggested are more substitutable with high-tech capital types, such as computers and software, that perform routine manual and cognitive tasks (Autor, Levy, and Murnane [2003]). In this section, we evaluate whether capital types differ in terms of their elasticity of substitution with labor.

To perform this evaluation, we extend the baseline production function regression to include interactions between log labor and each of the investment shares. The results are shown in Table 5; the coefficients on the non-interacted variables are shown in Column (1) while those on the labor interactions are shown in Column (2). As Special Industry Machinery is the omitted category for this regression (both its investment share and its interaction with labor are omitted), the coefficients in Column (2) indicate the degree of substitutability (negative coefficients) or complementarity (positive coefficients) between each capital type and labor relative to Special Industry Machinery's degree of substitutability with labor. Several interactions are found to be statistically significant, suggesting that capital types do differ in their elasticity of substitution with labor. Relative to other capital types, Software is found to be labor-saving (substitutable with labor) while General Purpose Machinery and Trucks are found to be labor-augmenting (complementary with labor).

As with the coefficients on the (non-interacted) investment shares, the choice of omitted capital type affects the point estimate and significance of the coefficients on the interactions, but it has no effect whatsoever on their relative values, i.e., the sum or difference, of any two coefficients. This can be verified by looking at the results one obtains if one omits a different capital type than Special Industry Machinery. Columns 3 and 4 show the results from instead omitting General Purpose Machinery (from the interacted investment shares). One may easily verify that the sum of the labor interaction coefficients for any two capital types is the same regardless of which capital type's interaction is omitted (note that because the coefficient values in Table 5 are only shown up to 2 digits, rounding error causes some sums to appear slightly different). Thus, as we do graphically in Figure 2, one can normalize the coefficients on the interactions by, for example, setting to zero the coefficient on the capital type with the lowest degree of substitutability with labor, which in this case happens to be Metalworking Machinery. This figure shows that Software is by far the most laborsaving capital good, with Office Equipment a distant second. Metalworking Machinery, 
Trucks, and General Purpose Machinery, in that order, are the least labor-saving (or, equivalently, the most labor-augmenting).

Given that aggregate data (e.g., BEA's Fixed Reproducible Tangible Wealth data) show that investment has shifted in recent years away from traditional equipment like Metalworking and General Purpose Machinery and toward the relatively laborsaving capital goods like Software, these results support the notion that part of the explanation for the so-called "jobless recovery" after the 2001 recession may be this shift toward relatively labor-saving technologies.

\section{Conclusion}

This paper has shown that, even controlling for other simultaneous physical capital investments, investment in ICT capital is positively associated with conventionallymeasured multi-factor productivity at the firm-level. This association is robust to including various controls for unobserved heterogeneity and simultaneity of input and output decisions, suggesting that at least part of the association is causal. Investment in Offices also has a positive association, though it goes away once one controls for firms' spending on selling, general, and administrative expenses, a proxy for organizational capital. In addition, the results presented in this paper imply that the marginal products of ICT capital goods are above official estimates of their rental prices (c.f. Table 3). One possible reason is that the rental price estimates, which are used in constructing the macroeconomic and industry data used in growth accounting studies, are too low for ICT capital goods. On the other hand, there may in fact be excess returns to these capital goods. Such excess returns could be due to unobserved complementary co-investments such as improvements in workplace practices, adjustment costs such as learning-by-doing, or expectational errors by firms in terms of the marginal products of their capital investments. These results suggest that the aggregate trend towards more use of ICT capital relative to other capital by U.S. businesses will be an important driver of labor productivity growth going forward.

Another important finding in this paper is evidence of complementarities and substitutabilities among different capital goods. In particular, the predominant pattern of the results suggests that goods typically classified as "high-tech" tend to be complements with "low-tech" goods and tend to be substitutes with other "high-tech" goods. This pattern is quite sensible from an economic point of view, though it 
contrasts with the prevailing popular view that high-tech capital goods are generally complementary to each other. The best explanation for this discrepancy is that the high-tech goods considered in this paper often already embed many of the characteristics that are generally associated with other high-tech goods.

Finally, we find that not only do certain types of capital affect the marginal products of other capital types, but they also affect the marginal product of labor. In particular, we find Software to be the most labor-saving capital good, while Metalworking Machinery, Trucks, and General Purpose Machinery are the most labor-augmenting capital goods.

A number of steps were taken in this paper to evaluate the direction of causality in the capital mix-productivity relationships. However, given the purely cross-sectional nature of the disaggregate investment data from the 1998 ACES and the large number of potentially endogenous investment shares (both a blessing and a curse of these data), it is impossible to fully disentangle the effect of investment/capital mix on productivity from possible feedback in the opposite direction. The most recent ACES survey (2003, data from which were not available at the time of this writing) collected such disaggregate investment detail again; these data, combined with the 1998 data, may allow future research to better address this issue.

\section{References}

\section{References}

[1] Arellano, Manuel, and Stephen R. Bond. "Some Tests of Specification for Panel Data: Monte Carlo Evidence and Application to Employment Equations." Review of Economic Studies 58 (1991): 277-97.

[2] Audretsch, David B., and Maryann P. Feldman. "R\&D Spillovers and the Geography of Innovation and Production." American Economic Review 86, no. 3 (1996): 630-640.

[3] Autor, David H., Frank Levy, and Richard J. Murnane. "The Skill Content of Recent Technological Change: An Empirical Exploration." Quarterly Journal of Economics 118, no. 4 (2003). 
[4] Bartel, Ann, Casey Ichniowski, and Kathryn Shaw. "The Effects of New Information Technologies and New Work Practices on Establishment Productivity: An "Insider" Econometric Analysis." Mimeo (2004).

[5] Bartel, Ann, Casey Ichniowski, and Kathryn Shaw. "'Insider Econometrics' and the Determinants of Productivity." American Economic Association 94, no. 2 (2004): 217-22.

[6] Basu, Susanto. "Procyclical Productivity: Increasing Returns or Cyclical Utilization." Quarterly Journal of Economics 111, no. 3 (1996): 719-51.

[7] Basu, Susanto, and John G. Fernald. "Are Apparent Productive Spillovers a Figment of Specification Error?" Journal of Monetary Economics 36 (1995): 165-88.

[8] Becker, Randy, John C. Haltiwanger, Ron S. Jarmin, Shawn Klimek, and Daniel J. Wilson. "Micro and Macro Data Integration: The Case of Capital." Conference draft for NBER/CRIW Conference in April 2004 on the Architecture of the National Accounts. http://www.nber.org/CRIW/CRIWs04/becker.pdf.

[9] Bahk, Byong-Hyong, and Michael Gort. "Decomposing Learning By Doing in New Plants." Journal of Political Economy 101, no. 4 (1993): 561-83.

[10] Berndt, Ernst R., and Catherine J. Morrison. "High-Tech Capital Formation and Economic Performance in U.S. Manufacturing Industries: An Exploratory Analysis." Journal of Econometrics 65, no. 1 (1995): 9-43.

[11] Black, Sandra E., and Lisa M. Lynch. "How to Compete: The Impact of Workplace Practices and Information Technology on Productivity." Review of Economics and Statistics 83, no. 3 (2001): 434-45.

[12] Bresnahan, Timothy F., Erik Brynjolfsson, and Lorin M. Hitt. "Information Technology, Work Organizational and the Demand for Skilled Labor: Firm-level Evidence." Quarterly Journal of Economics 117 (2002): 339-76.

[13] Bresnahan, Timothy F., and Shane Greenstein. "Technical Progress and CoInvention in Computing and in the Uses of Computers." Brookings Papers on Economic Activity, Microeconomics (1996): 1-77. 
[14] Bresnahan, Timothy F., and Manuel Trajtenberg. "General Purpose Technologies - "Engines of Growth?"” Journal of Econometrics 65, no. 1 (1995): 83-108.

[15] Brynjolfsson, Erik, and Lorin M. Hitt. "Information Technology as a Factor of Production: The Role of Differences Among Firms." Economics of Innovation and New Technology 3, no. 4 (1995): 183-200.

[16] Brynjolfsson, Erik, and Lorin M. Hitt. "Paradox Lost? Firm-level Evidence on the returns to information systems spending." Management Science 42, no. 4 (1996): $541-48$.

[17] Brynjolfsson, Erik, and Lorin M. Hitt. "Computing Productivity: Firm-Level Evidence." Review of Economics and Statistics 85, no. 4 (2003): 793-808.

[18] Brynjolfsson, Erik, Lorin M. Hitt, and Shinkyu Yang. "Intangible Assets: Computers and Organizational Capital." Brookings Papers on Economic Activity, no. 1 (2002): 137-82.

[19] Burnside, Craig, Martin Eichenbaum, and Sergio Rebelo. "Capital Utilization and Returns to Scale." NBER Macroeconomics Annual 10 (1995).

[20] Caselli, Francesco, and Daniel J. Wilson. "Importing Technology." Journal of Monetary Economics 51, no. 1 (2004): 1-32.

[21] Census Bureau. "Annual Capital Expenditures, 1998." (2000). Available online at: http://www.census.gov/csd/ace/.

[22] Chirinko, Robert S. "Multiple Capital Inputs, Q, and Investment Spending." Journal of Economic Dynamics and Control 17 (1993): 907-28.

[23] Ciccone, Antonio, and Robert E. Hall. "Productivity and the Density of Economic Activity." American Economic Review 86, no. 1 (1996): 54-70.

[24] Cummins, Jason and Matthew Dey. "Taxation, Investment, and Firm Growth with Heterogeneous Capital." Mimeo, University of Chicago (1998). Available online at: http://home.uchicago.edu/ ${ }^{\sim}$ mdey/cdes.pdf

[25] Cummins, Jason, Kevin A. Hassett, and R. Glenn Hubbard. "A Reconsideration of Investment Behavior using Tax Reforms as Natural Experiments." Brookings Papers on Economic Activity 1994, no. 2 (1994): 1-74. 
[26] David, Paul A. "The Dynamo and the Computer: A Historical Perspective on the Modern Productivity Paradox." American Economic Review Papers and Proceedings 80, no. 2 (1990): 355-61.

[27] Denny, Michael, and J. Douglas May (1978). "Homotheticity and real value-added in Canadian Manufacturing." In M. Fuss and D. McFadden (Eds.), Production Economics: A Dual Approach to Theory and Applications, Volume 2, pp. 53-70. Amsterdan: North-Holland Publishing Company.

[28] Doms, Mark E., and Timothy Dunne. "Capital Adjustment Patterns in Manufacturing Plants." Review of Economic Dynamics 1, no. 2 (1998): 409-29.

[29] Dunne, Timothy, Lucia Foster, John C. Haltiwanger, and Kenneth R. Troske. "Wage and Productivity Dispersion in U.S. Manufacturing: The Role of Computer Investment." Journal of Labor Economics 22, no. 2 (2004): 397-429.

[30] Ellison, Glenn, and Edward L. Glaeser. 1999. "The Geographic Concentration of U.S. Industry: Does Natural Advantage Explain Agglomeration." American Economic Review 89(2) (May) pp. 311-316.

[31] Fisher, Franklin M. "Embodied Technical Change and the Existence of an Aggregate Capital Stock." Review of Economic Studies 32 (1965): 263-88.

[32] Gera, Surendra, Wulong Gu, and Frank C. Lee. "Information Technology and Labour Productivity Growth: An Empirical Analysis for Canada and the United States." Canadian Journal of Economics 32, no. 2 (1999): 384-407.

[33] Gilchrist, Simon, Vijay Gurbaxani, and Robert Town. "Productivity and the PC Revolution." Mimeo (2003).

[34] Goolsbee, Austan. "Taxes And The Quality Of Capital." Journal of Public Economics 88, no. 3-4 (2004): 519-43.

[35] Gordon, Robert. "Does the 'New Economy' Measure Up to the Great Inventions of the Past?" Journal of Economic Perspectives 14, no. 4 (2000): 49-74.

[36] Greenan, Nathalie, and Jacques Mairesse. "Computers and Productivity in France: Some Evidence." Economics of Innovation and New Technology 9, no. 3 (2000): 275-315. 
[37] Griliches, Zvi, and Donald Siegel. "Purchased Services, Outsourcing, Computers, and Productivity in Manufacturing." Output Measurement in the Service Sectors, National Bureau of Economic Research Studies in Income and Wealth. Editors Ernst R. Berndt, Timothy F. Bresnahan, and Marilyn E. Manser. Vol. 56. Chicago and London: University of Chicago Press, 1992.

[38] Hall, Robert E., and Dale W. Jorgenson. "Tax Policy and Investment Behavior." American Economic Review 57 (1967): 391-414.

[39] Hempell, Thomas. "What's Spurious, What's Real? Measuring the Productivity Impacts of ICT at the Firm-Level." Empirical Economics 30, no. 2 (2005): 427-64.

[40] Hayashi, Fumio, and Tohru Inoue. "The Relation Between Firm Growth and Q with Multiple Capital Goods: Theory and Evidence from Panel Data on Japanese Firms." Econometrica 59, no. 3 (1991): 731-53.

[41] House, Christopher L., and Matthew D. Shapiro. "Temporary Investment Tax Incentives: Theory with Evidence from Bonus Depreciation." NBER Working Paper 12514 (2006).

[42] Jorgenson, Dale W. "Capital Theory and Investment Behavior." American Economic Review 53, no. 2 (1963): pp. 247-59.

[43] Jorgenson, Dale W., and Zvi Griliches. "The Explanation of Productivity Change." Review of Economic Studies, no. 34 (1967): 249-83.

[44] Jorgenson, Dale W, and Kevin J. Stiroh. "Raising the Speed Limit: U.S. Economic Growth in the Information Age." Brookings Papers on Economic Activity 2000, no. 1 (2000): 125-212.

[45] Lehr, Bill, and Frank R. Lichtenberg. "Information Technology and Its Impact on Productivity: Firm-Level Evidence From Government and Private Data Sources, 1977-1993." Canadian Journal of Economics 32, no. 2 (1999): 335-62.

[46] Lev, Baruch, and Suresh Radhakrishnan. "The Valuation of Organization Capital," in Corrado, Haltiwanger, and Sichel (Eds.), Measuring Capital in a New Economy, National Bureau of Economic Research and University of Chicago Press (2005): 73-99. 
[47] Oliner, Stephen D., and Daniel E. Sichel. "Computers and Output Growth Revisited: How Big Is the Puzzle?" Brookings Papers on Economic Activity 2 (1994): 273-317.

[48] Oliner, Stephen D., and Daniel E. Sichel. "The Resurgence of Growth in the Late 1990s: Is Information Technology the Story?" Journal of Economic Perspectives 14, no. 4 (2000): 3-22.

[49] Olley, Steven G. and Ariel Pakes. "The Dynamics of Productivity in the Telecommunications Equipment Industry." Econometrica 64, no. 4 (1996): 1263-97.

[50] Solow, Robert M. "The Production Function and The Theory of Capital." Review of Economic Studies 23, no. 2 (1955-1956): 101-8.

[51] Stiroh, Kevin. "Are ICT Spillovers Driving the New Economy." Review of Income and Wealth 48, no. 1 (2002): 33-57.

[52] Stiroh, Kevin. "Reassessing the Impact of IT in the Production Function: A MetaAnalysis." Annales d'Economie et de Statistique (forthcoming).

[53] Wilson, Daniel J. "Is Embodied Technology the Result of Upstream R\&D? Industry-Level Evidence." Review of Economic Dynamics 5 (2002): 285-317.

[54] Wilson, Daniel J. "Investment Behavior of U.S. Firms over Heterogeneous Capital Goods.” Federal Reserve Bank of San Francisco Working Paper 2004-21 (2004).

\section{Appendix A - Variable construction}

The following is a list of the key variables used in this paper and how they were constructed from the data at hand:

Real Output - Real Output is obtained by dividing Compustat's sales variable (SALES_NET - \#A12) by the BEA's 3-digit SIC level gross output deflator (P): Y $=$ SALES_NET $/ \mathrm{P}$.

Total capital - Total capital $(\mathrm{K})$ is obtained by deflating Compustat's Property, Plant, and Equipment (Total - Gross) (PPEGT) by the BLS's 2-digit total investment deflators. Following Brynjolfsson and Hitt (2003), the deflator is applied at the calculated average age of capital, based on a 3 -year ( $t, t-1, t-2)$ average of the ratio of 
total accumulated depreciation (ACC_DEPR) to current depreciation (Depreciation and Amortization: DP). ACC_DEPR is calculated as Property, Plant, and Equipment (Total - Gross) minus Property, Plant \& Equipment (Total - Net): ACC_DEPR = PPEGT - PPENT. A preferable method for measuring the capital stock would have been the perpetual inventory method. However, the necessary long time series of past annual investment is not available. Fortunately, it has been shown that the book value capital stock yields virtually identical results in production function regressions to perpetual inventory capital stock. ${ }^{44}$

Labor - The labor input (L) is measured as the number of employees (EMP) reported in Compustat.

Wages and Labor Costs - For a subset of firms, Compustat provides data on Labor and Related Expenses (XLR). For these firms, the average wage can be obtained by dividing XLR by EMP. For firms with missing values for XLR, we impute the average wage by multiplying the firm's number of employees (EMP) by the 3-digit industry mean of average wages, computed over firms with nonmissing values for XLR. If there 2 or fewer firms with nonmissing XLR in that 3-digit industry, we use the 2-digit industry mean. XLR for firms with missing values is then imputed by taking the product of the imputed average wage and the reported value of EMP.

Nominal Materials Costs - Nominal materials (PM) are calculated (using Compustat) as sales net of Operating Income Before Depreciation (OIDBP) and Labor and Related Expenses (XLR):

$\mathrm{PM}=\mathrm{SALES} \_\mathrm{NET}-\mathrm{OIDBP}-\mathrm{XLR}$.

An equivalent definition is Cost of Goods Sold (COGS) plus Selling, General, and Administrative Expense (XSGA) minus XLR:

$\mathrm{PM}=\mathrm{COGS}+\mathrm{XSGA}-\mathrm{wL}$.

The two definitions are equivalent since OIDBP is defined as SALES_NETCOGS-XSGA. We use the first definition unless it yields a missing value in which case we use the second definition.

Real Materials Costs - Real materials costs (M) are calculated as nominal materials (PM) deflated by the BEA's 3-digit gross output deflator $(\mathrm{P})$. Unfortunately, no separate deflator exists that is specific to materials.

Solow Residual (SRD) - The natural log of 2-factor productivity (2FP), which is the dependent variable in the $2 \mathrm{FP}$ regressions, is computed using the following

\footnotetext{
${ }^{44}$ See Becker, et al. (2004).
} 
formula:

$$
S R D=\ln (Y)-\left(\frac{r K}{P Y}\right) \ln (K)-\left(\frac{w L}{P Y}\right) \ln (L)
$$

where $r$ is the capital rental price, obtained at the 2-digit SIC level from the BLS. $w L$ comes from Compustat's variable, Labor and Related Expenses (XLR).

Investment Spike - The investment spike dummy variable (SPIKE) is 1 if current total investment is equal to or greater than $20 \%$ of $\mathrm{K}$; 0 otherwise.

Employment Size - The employment size class indicator (SIZE) can take on five values:

$$
\begin{aligned}
& \mathrm{SIZE}=1 \text { if } \mathrm{L}<1000 \\
& \mathrm{SIZE}=2 \text { if } 1000 \leq \mathrm{L}<2000 \\
& \mathrm{SIZE}=3 \text { if } 2000 \leq \mathrm{L}<4500 \\
& \mathrm{SIZE}=4 \text { if } 4500 \leq \mathrm{L}<11500 \\
& \mathrm{SIZE}=5 \text { if } 11500 \leq \mathrm{L}
\end{aligned}
$$




\begin{tabular}{|c|c|c|}
\hline \multicolumn{3}{|c|}{ Appendix B. ACES asset types and aggregated categories used in regressions } \\
\hline Original ACES Asset Type Codes & Description & Aggregated Category Names \\
\hline \multicolumn{3}{|c|}{ Equipment } \\
\hline 311 & Computer and Peripheral Equipment & Computers \\
\hline 312 & Office Equipment Except Computers and Peripherals & Office Equipment \\
\hline 313 & Communications, Audio, and Video Equipment & Communications and AV Equipment \\
\hline 314 & Navigational, Measuring, Electromedical, and Control Instruments & \multirow{2}{*}{ Instruments } \\
\hline 315 & Medical Equipment and Supplies & \\
\hline 316 & Capitalized Software Purchased Separately & Software \\
\hline 321 & Fabricated Metal Products & Fabricated Metal Products \\
\hline 322 & Metalworking Machinery & Metalworking Machinery \\
\hline 323 & Special Industrial Machinery & Special Industrial Machinery \\
\hline 324 & $\begin{array}{l}\text { Ventilation, Heating, Air-Conditioning, Commercial Refrigeration, and } \\
\text { Other General Purpose Machinery }\end{array}$ & General Purpose Machinery \\
\hline 331 & Cars and Light Trucks & Autos \\
\hline 332 & Heavy Duty Trucks & Trucks \\
\hline 333 & Aerospace Products and Parts & Aircraft \\
\hline 334 & Other Transportation Equipment & Other Transportation Equipment \\
\hline 341 & Engine, Turbine, and Power Transmission Equipment & \multirow{3}{*}{ Electrical Equipment } \\
\hline 342 & Electrical Transmission and Distribution Equipment & \\
\hline 343 & Electrical Equipment, NEC & \\
\hline 344 & Mining and Oil and Gas Field Machinery and Equipment & \multirow{9}{*}{ Miscellaneous Equipment } \\
\hline 345 & Floating Oil and Gas Drilling and Production Platforms & \\
\hline 346 & Nuclear Fuel & \\
\hline 351 & Furniture and Related Products & \\
\hline 352 & Agricultural Equipment & \\
\hline 353 & Construction Machinery & \\
\hline 354 & Service Industry Equipment & \\
\hline 355 & Other Miscellaneous Equipment & \\
\hline 361 & Artwork, Books, and Other Equipment, NEC & \\
\hline
\end{tabular}


TABLE 1 continued...

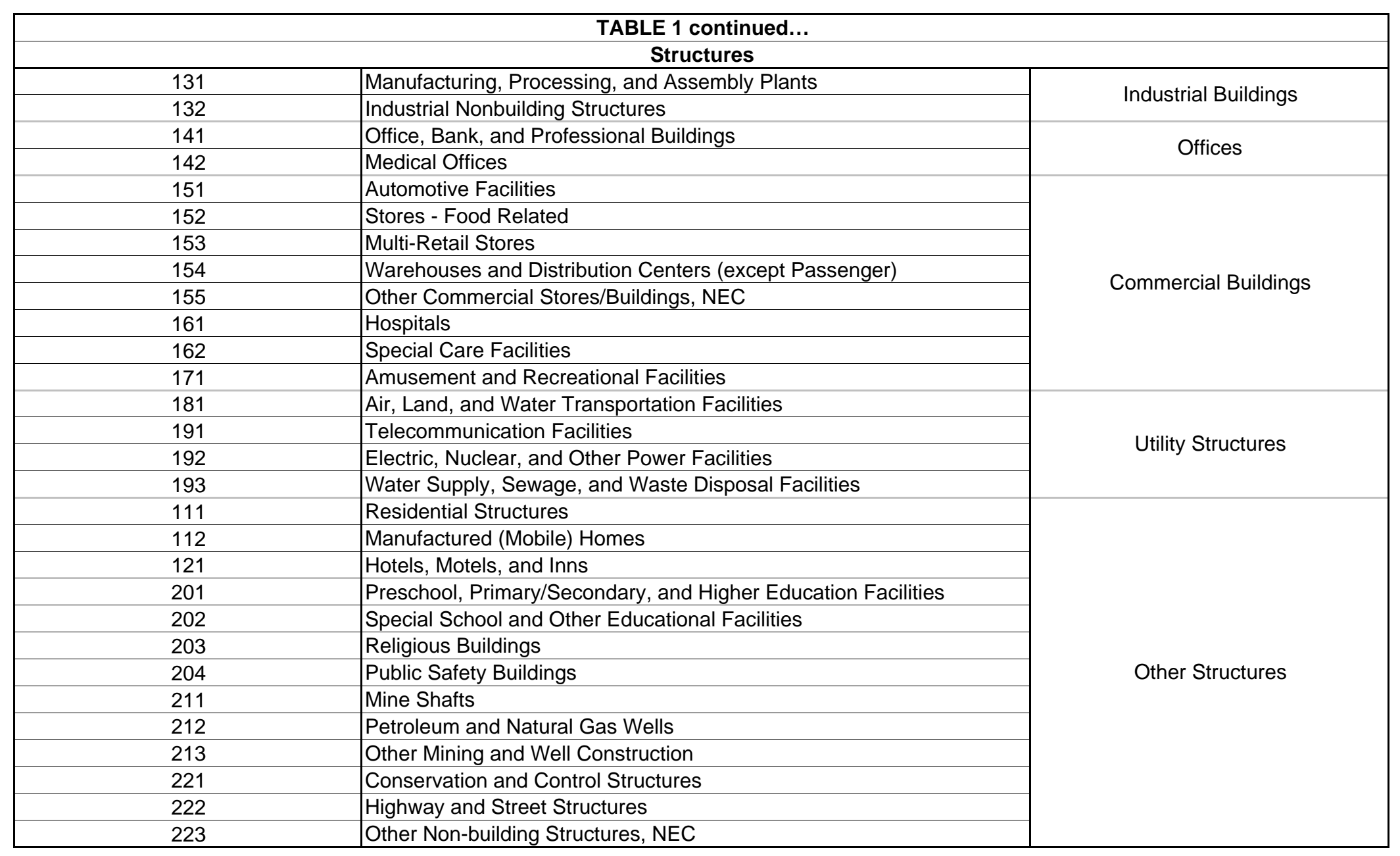


Appendix C. Results from 1999 Cross-Section

(Using 1998 Investment Shares)

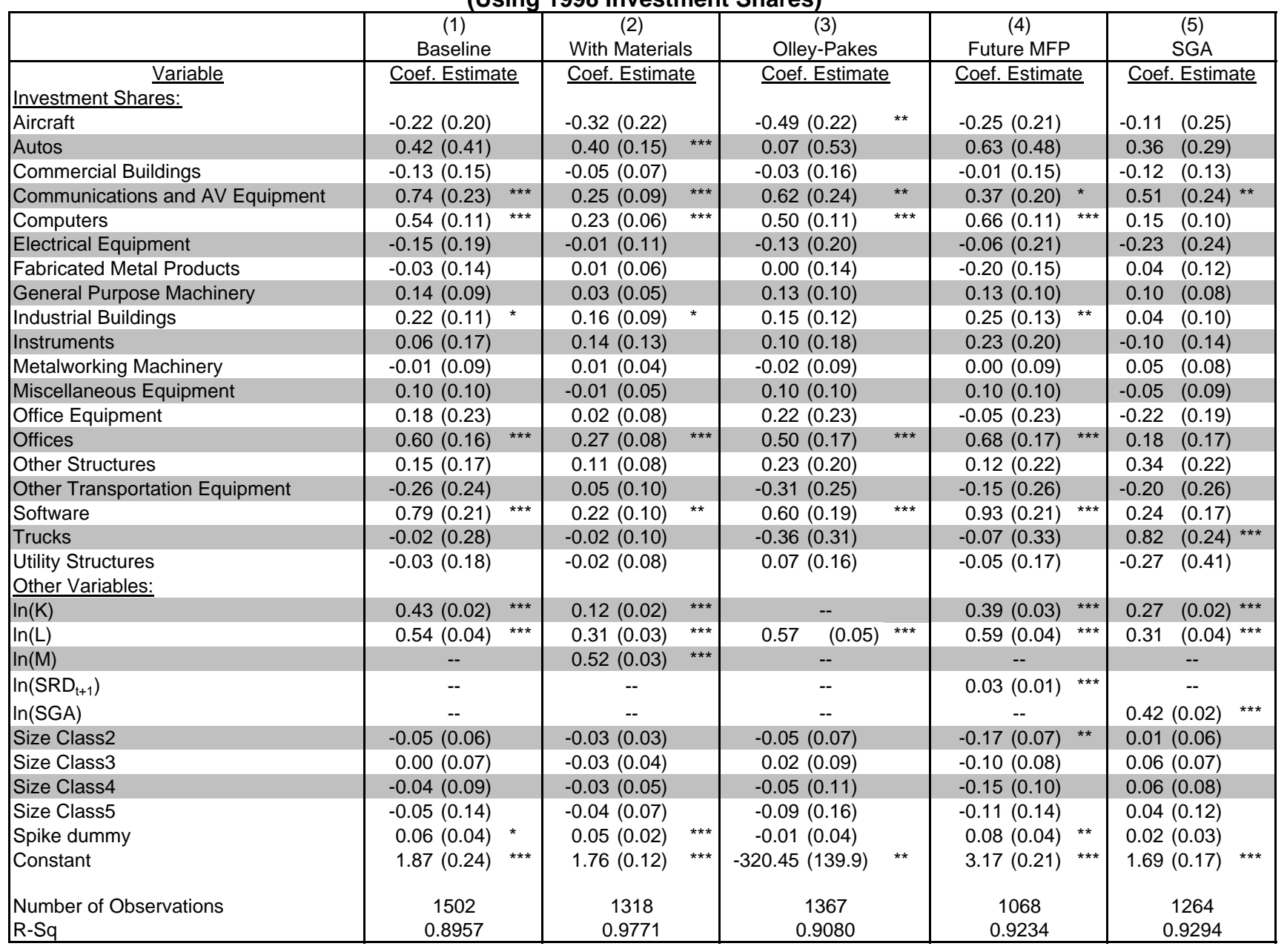

Notes: These regressions also include 3-digit SIC industry dummies and state dummies, though due to confidentiality

concerns, the coefficients on these dummies are not shown. In addition, Column (3) contains all terms, including interactions,

of a 3rd-order polynomial in (I, K, and Age)

Robust standard errors are shown in parentheses.

*** denotes significance at the $99 \%$ level

** denotes significance at the $95 \%$ level

* denotes significance at the $90 \%$ level 
Figure 1. Implied Marginal Products and BLS Rental Prices

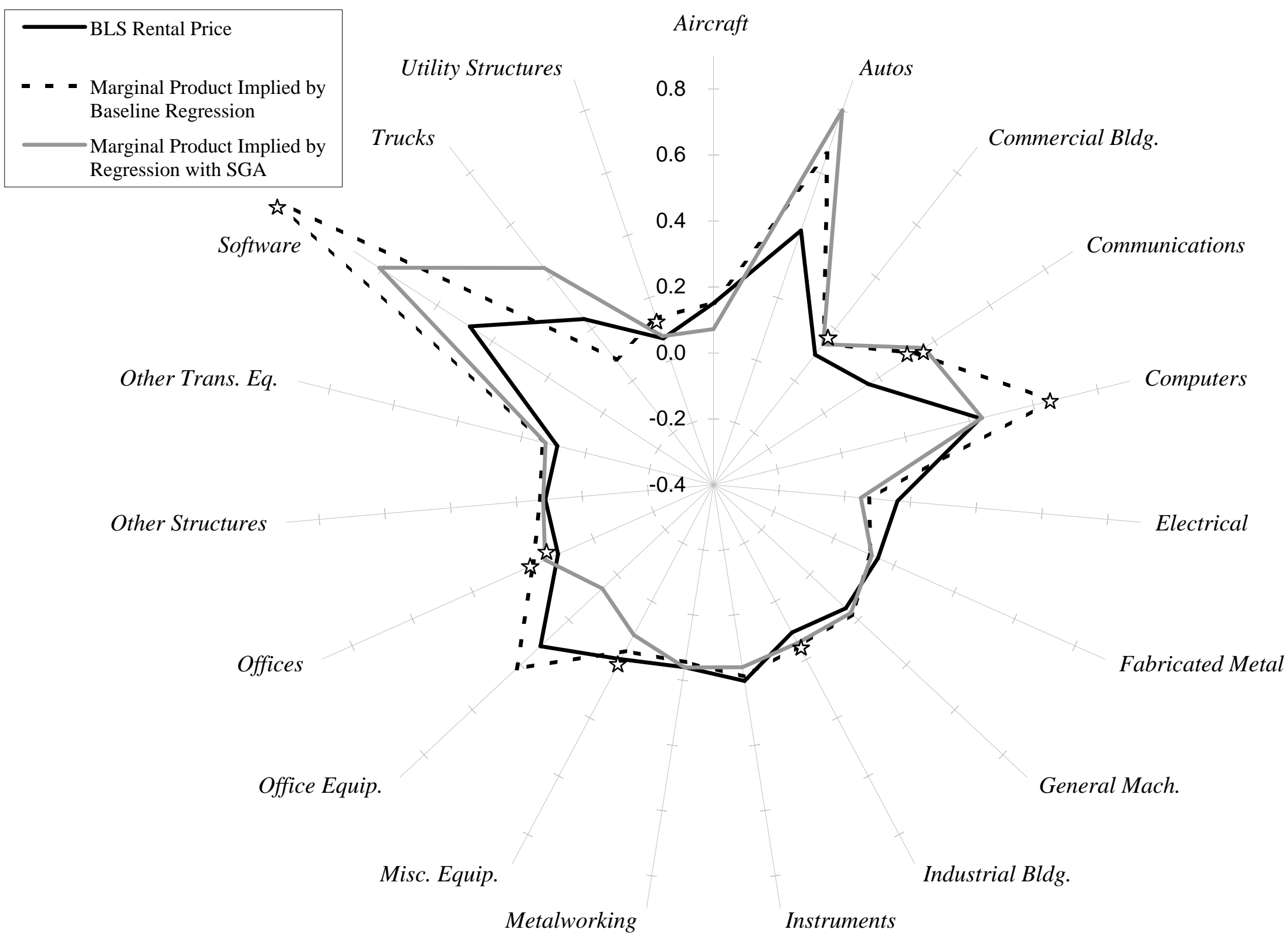


Figure 2. Association Between Output and Labor-Capital Interactions

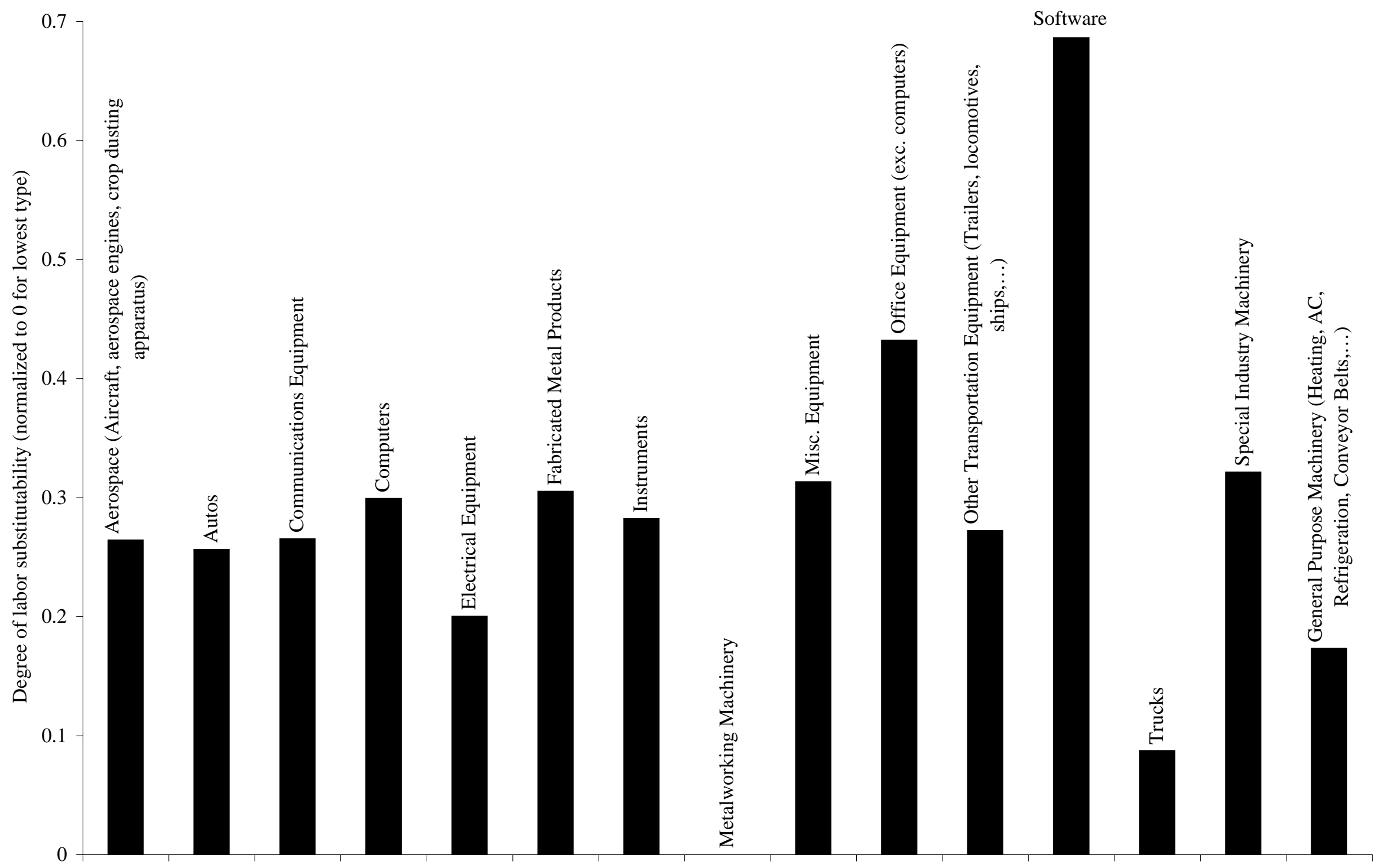


Table 1. Summary Statistics

\begin{tabular}{|c|c|c|c|}
\hline Variable & Mean & Standard Deviation & Correlation with Sales ${ }^{1}$ \\
\hline Sales & 2344 & 7499 & - \\
\hline K & 2377 & 9055 & 0.796 \\
\hline L & 12.471 & 38.810 & 0.714 \\
\hline Spike & 0.316 & 0.465 & -0.025 \\
\hline Size Class1 & 0.159 & 0.222 & -0.125 \\
\hline Size Class2 & 0.193 & 0.395 & -0.130 \\
\hline Size Class3 & 0.221 & 0.415 & -0.119 \\
\hline Size Class4 & 0.212 & 0.409 & -0.053 \\
\hline Size Class5 & 0.215 & 0.411 & 0.409 \\
\hline Aircraft & 0.011 & 0.087 & 0.380 \\
\hline Autos & 0.015 & 0.074 & 0.258 \\
\hline Commercial Buildings & 0.027 & 0.129 & 0.020 \\
\hline Communications and AV Equipment & 0.030 & 0.119 & 0.028 \\
\hline Computers & 0.155 & 0.222 & -0.011 \\
\hline Electrical Equipment & 0.049 & 0.119 & 0.015 \\
\hline Fabricated Metal Products & 0.014 & 0.083 & -0.023 \\
\hline General Purpose Machinery & 0.046 & 0.140 & -0.009 \\
\hline Industrial Buildings & 0.088 & 0.192 & 0.217 \\
\hline Instruments & 0.080 & 0.141 & -0.023 \\
\hline Metalworking Machinery & 0.065 & 0.187 & -0.037 \\
\hline Miscellaneous Equipment & 0.108 & 0.195 & -0.021 \\
\hline Office Equipment & 0.019 & 0.070 & -0.011 \\
\hline Offices & 0.035 & 0.146 & -0.023 \\
\hline Other Structures & 0.021 & 0.112 & 0.006 \\
\hline Other Transportation Equipment & 0.015 & 0.084 & -0.011 \\
\hline Software & 0.036 & 0.099 & -0.044 \\
\hline Special Industrial Machinery & 0.156 & 0.276 & -0.025 \\
\hline Trucks & 0.011 & 0.074 & -0.015 \\
\hline Utilities & 0.018 & 0.088 & 0.002 \\
\hline Number of Equipment Types & 4.563 & 3.136 & - \\
\hline Number of Structure Types & 1.655 & 1.167 & - \\
\hline Number of Observations & 1650 & & \\
\hline
\end{tabular}

${ }^{\mathrm{I}}$ Partial correlations controlling for 3-digit SIC industry dummy variables. 
Table 2. Production Function Regressions

\begin{tabular}{|c|c|c|c|c|c|c|c|c|c|c|}
\hline & \multicolumn{3}{|c|}{$\begin{array}{c}(1) \\
\text { Baseline }\end{array}$} & \multicolumn{2}{|c|}{$\begin{array}{c}(2) \\
\text { With Materials }\end{array}$} & \multicolumn{2}{|l|}{$\begin{array}{c}\text { (3) } \\
\text { Olley-Pakes }\end{array}$} & \multicolumn{2}{|l|}{$\begin{array}{c}(4) \\
\text { With } \mathrm{SRD}_{\mathrm{t}+1} \\
\end{array}$} & $\begin{array}{c}\text { (5) } \\
\text { With SGA }\end{array}$ \\
\hline $\begin{array}{l}\text { Variable } \\
\text { Investment Shares: }\end{array}$ & Coef & Estimate & & Coef. Estima & & Coef. Estimate & & Coef. Estimat & & Coef. Estimate \\
\hline Aircraft & 0.03 & $(0.15)$ & & $-0.29(0.19)$ & & $0.01(0.19)$ & & $-0.03(0.18)$ & & $-0.16 \quad(0.15)$ \\
\hline Autos & 0.48 & $(0.32)$ & & $0.29(0.14)$ & ** & $0.30(0.42)$ & & $0.56(0.41)$ & & $0.39 \quad(0.27)$ \\
\hline Commercial Buildings & -0.06 & $(0.14)$ & & $-0.03(0.07)$ & & $0.00(0.15)$ & & $-0.03(0.16)$ & & $-0.05(0.12)$ \\
\hline Communications and AV Equipment & 0.70 & $(0.26)$ & $\star \star \star *$ & $0.12(0.08)$ & & $0.52(0.22)$ & ** & $0.42(0.28)$ & & $0.52(0.26)$ ** \\
\hline Computers & 0.54 & $(0.10)$ & $\star \star \star *$ & $0.21(0.05)$ & *** & $0.56(0.10)$ & $\star * \star *$ & $0.52(0.11)$ & $\star \star \star *$ & $0.20(0.09)$ ** \\
\hline Electrical Equipment & -0.23 & $(0.17)$ & & $-0.07(0.09)$ & & $-0.24(0.17)$ & & $-0.16(0.19)$ & & $-0.20(0.24)$ \\
\hline Fabricated Metal Products & -0.10 & $(0.12)$ & & $0.07(0.06)$ & & $0.00(0.13)$ & & $-0.07(0.12)$ & & $-0.05 \quad(0.11)$ \\
\hline General Purpose Machinery & 0.11 & $(0.09)$ & & $-0.03(0.04)$ & & $0.01(0.10)$ & & $0.08(0.10)$ & & $0.06 \quad(0.08)$ \\
\hline Industrial Buildings & 0.11 & $(0.11)$ & & $0.10(0.05)$ & * & $0.14(0.11)$ & & $0.10(0.12)$ & & $-0.01 \quad(0.10)$ \\
\hline Instruments & 0.10 & $(0.17)$ & & $0.17(0.12)$ & & $0.17(0.16)$ & & $0.14(0.15)$ & & $0.02(0.18)$ \\
\hline Metalworking Machinery & 0.00 & $(0.08)$ & & $-0.11(0.13)$ & & $0.03(0.08)$ & & $-0.02(0.08)$ & & $0.03 \quad(0.07)$ \\
\hline Miscellaneous Equipment & 0.06 & $(0.10)$ & & $0.02(0.05)$ & & $0.11(0.10)$ & & $0.02(0.10)$ & & $-0.04(0.08)$ \\
\hline Office Equipment & 0.30 & $(0.22)$ & & $0.05(0.07)$ & & $0.13(0.21)$ & & $-0.15(0.22)$ & & $-0.06(0.19)$ \\
\hline Offices & 0.57 & $(0.15)$ & $\star \star \star$ & $0.41(0.11)$ & 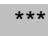 & $0.55(0.16)$ & $\star \star \star \star$ & $0.68(0.18)$ & 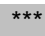 & $0.09 \quad(0.15)$ \\
\hline Other Structures & -0.12 & $(0.16)$ & & $-0.02(0.10)$ & & $-0.23(0.15)$ & & $-0.24(0.17)$ & & $-0.13(0.19)$ \\
\hline Other Transportation Equipment & -0.07 & $(0.21)$ & & $-0.22(0.11)$ & ** & $-0.14(0.23)$ & & $-0.10(0.25)$ & & $-0.08 \quad(0.21)$ \\
\hline Software & 0.81 & $(0.19)$ & $\star \star \star *$ & $0.28(0.08)$ & *** & $0.78(0.17)$ & $\star * \star *$ & $0.96(0.25)$ & *** & $0.33(0.15)$ ** \\
\hline Trucks & -0.13 & $(0.22)$ & & $-0.11(0.13)$ & & $-0.11(0.29)$ & & $0.05(0.27)$ & & $0.38 \quad(0.24)$ \\
\hline $\begin{array}{l}\text { Utility Structures } \\
\text { Other Variables: }\end{array}$ & -0.17 & $(0.22)$ & & $-0.06(0.06)$ & & $-0.07(0.15)$ & & $-0.13(0.16)$ & & $-0.67 \quad(0.51)$ \\
\hline $\ln (K)$ & 0.42 & $(0.02)$ & *** & $0.13(0.01)$ & $* * *$ & -- & & $0.39(0.02)$ & *** & $0.27(0.02) * * \star$ \\
\hline $\ln (\mathrm{L})$ & 0.53 & $(0.04)$ & $\star \star \star *$ & $0.30(0.03)$ & *** & $0.53 \quad(0.05)$ & *** & $0.57(0.05)$ & *** & $0.30(0.04) * * *$ \\
\hline $\ln (\mathrm{M})$ & & & & $0.56(0.02)$ & 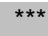 & -- & & -- & & -- \\
\hline $\ln \left(S_{R} D_{t+1}\right)$ & & -- & & -- & & -- & & $0.04(0.01)$ & $\star \star \star *$ & -- \\
\hline $\ln (\mathrm{SGA})$ & & -- & & -- & & -- & & -- & & 0.38 \\
\hline Size Class2 & -0.06 & $(0.06)$ & & $0.00(0.03)$ & & $-0.01(0.06)$ & & $-0.04(0.06)$ & & $0.00(0.05)$ \\
\hline Size Class3 & -0.01 & $(0.07)$ & & $0.00(0.04)$ & & $0.06(0.08)$ & & $-0.02(0.08)$ & & $0.06(0.06)$ \\
\hline Size Class 4 & -0.06 & $(0.09)$ & & $0.01(0.05)$ & & $0.01(0.11)$ & & $-0.07(0.10)$ & & $0.07(0.08)$ \\
\hline Size Class5 & 0.01 & $(0.13)$ & & $-0.01(0.07)$ & & $0.07(0.15)$ & & $-0.01(0.15)$ & & $0.15(0.11)$ \\
\hline Spike dummy & 0.05 & $(0.04)$ & & $0.05(0.02)$ & *** & $-0.03(0.04)$ & & $0.07(0.04)$ & * & $0.03(0.03)$ \\
\hline Constant & 3.35 & $(0.16)$ & *** & $2.01(0.12)$ & $* * *$ & $-55.38(133.6)$ & & $3.18(0.18)$ & $\star * \star$ & $2.53(0.14) \quad * * *$ \\
\hline Number of Observations & & 651 & & 1409 & & 1457 & & 1201 & & 1394 \\
\hline $\mathrm{R}-\mathrm{Sq}$ & & 8959 & & 0.9780 & & 0.9201 & & 0.9204 & & 0.9247 \\
\hline
\end{tabular}

Notes: These regressions also include 3-digit SIC industry dummies and state dummies, though due to confidentiality concerns,

the coefficients on these dummies are not shown. In addition, Column (3) contains all terms, including interactions, of a 3rd-

order polynomial in (I, K, and Age)

Robust standard errors are shown in parentheses.

*** denotes significance at the $99 \%$ level

** denotes significance at the $95 \%$ level

* denotes significance at the $90 \%$ level 
Table 3. Marginal Products Implied by Baseline Regression Results

\begin{tabular}{|c|c|c|c|c|c|}
\hline Capital Type & $\begin{array}{c}\text { Official (BLS) rental } \\
\text { price/user cost } \\
(1)\end{array}$ & $\begin{array}{r}\mathrm{Ma} \\
\text { Impl }\end{array}$ & & $\begin{array}{c}\text { Marginal Product } \\
\text { Implied by Regression } \\
\text { with SGA } \\
\text { (3) }\end{array}$ & $\begin{array}{c}\text { BLS Depreciation } \\
\text { rate }^{2} \\
(4)\end{array}$ \\
\hline Aircraft & 0.15 & 0.15 & & 0.07 & 0.08 \\
\hline Autos & 0.41 & 0.66 & & 0.80 & 0.30 \\
\hline Commercial Buildings & 0.10 & 0.14 & $\star \star \star$ & $0.14 * \star \star$ & 0.01 \\
\hline Communications and AV Equipment & 0.16 & 0.33 & ** & $0.36 *$ & 0.08 \\
\hline Computers & 0.43 & 0.66 & $\star \star$ & 0.44 & 0.27 \\
\hline Electrical Equipment & 0.16 & 0.07 & & 0.05 & 0.09 \\
\hline Fabricated Metal Products & 0.15 & 0.12 & & 0.13 & 0.07 \\
\hline General Purpose Machinery & 0.15 & 0.18 & & 0.17 & 0.08 \\
\hline Industrial Buildings & 0.11 & 0.15 & $\star \star \star$ & $0.14 * \star \star$ & 0.02 \\
\hline Instruments & 0.20 & 0.19 & & 0.16 & 0.12 \\
\hline Metalworking Machinery & 0.16 & 0.14 & & 0.16 & 0.09 \\
\hline Miscellaneous Equipment & 0.20 & 0.17 & & 0.12 * & 0.13 \\
\hline Office Equipment & 0.32 & 0.42 & & 0.06 & 0.26 \\
\hline Offices & 0.12 & 0.20 & $\star \star \star \star ~$ & $0.16 * \star \star$ & 0.03 \\
\hline Other Structures & 0.11 & 0.13 & & 0.12 & 0.04 \\
\hline Other Transportation Equipment & 0.09 & 0.13 & & 0.13 & 0.04 \\
\hline Software & 0.48 & 1.19 & $\star \star \star$ & 0.81 & 0.37 \\
\hline Trucks & 0.24 & 0.08 & & 0.43 & 0.14 \\
\hline Utility Structures & 0.07 & 0.13 & $\star \star \star$ & 0.08 & 0.02 \\
\hline
\end{tabular}

${ }^{1}$ Calculated as: [(inv. share coefficient/capital elasticity $) *(B L S$ relative depreciation rate $\left.\left.)+1\right]\right]^{\star}(B L S$ rental price for Special Ind. Machinery). The BLS estimate of the user cost for Special Industry Machinery is 0.1449283 .

${ }^{2}$ The BLS estimate of the depreciation rate for total capital is 0.0980 .

Asterisks indicate implied marginal product is significantly different than official (BLS) rental price (assuming only source of randomness in above formula comes from the inv. share coefficient).

*** denotes significance at the $99 \%$ level

** denotes significance at the $95 \%$ level

* denotes significance at the $90 \%$ level 
Table 4. Regressions with three categories of type interactions

\begin{tabular}{|c|c|c|}
\hline & $\begin{array}{c}(1) \\
1998\end{array}$ & $\begin{array}{c}(2) \\
1999\end{array}$ \\
\hline Variable & Coef. Estimate & Coef. Estimate \\
\hline $\begin{array}{l}\text { Investment Shares: } \\
\text { Aircraft }\end{array}$ & $0.08(0.15)$ & $-0.11(0.20)$ \\
\hline Autos & $0.50(0.32)$ & $0.44(0.41)$ \\
\hline Commercial Buildings & $-0.04(0.15)$ & $-0.12(0.16)$ \\
\hline Communications and AV Equipment & 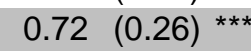 & $0.78(0.23)^{* \star \star}$ \\
\hline Computers & $0.53(0.10) * * \star$ & $0.54(0.11) * * \star$ \\
\hline Electrical Equipment & $-0.21(0.17)$ & $-0.11(0.19)$ \\
\hline Fabricated Metal Products & $-0.06(0.13)$ & $0.00(0.15)$ \\
\hline General Purpose Machinery & $0.15(0.10)$ & $0.20(0.10) *$ \\
\hline Industrial Buildings & $0.02(0.12)$ & $0.09(0.12)$ \\
\hline Instruments & $0.10(0.17)$ & $0.05(0.17)$ \\
\hline Metalworking Machinery & $0.02(0.08)$ & $0.03 \quad(0.09)$ \\
\hline Miscellaneous Equipment & $0.10(0.12)$ & $0.12(0.13)$ \\
\hline Office Equipment & $0.29(0.23)$ & $0.14(0.24)$ \\
\hline Offices & $0.52(0.17)^{\star \star \star}$ & $0.50(0.17)^{\star \star \star}$ \\
\hline Other Structures & $-0.07(0.17)$ & $0.18(0.18)$ \\
\hline Other Transportation Equipment & $-0.06(0.21)$ & $-0.27(0.26)$ \\
\hline Software & 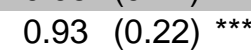 & $0.96(0.25) * * \star$ \\
\hline Trucks & $-0.07(0.23)$ & $0.00 \quad(0.30)$ \\
\hline $\begin{array}{l}\text { Utility Structures } \\
\text { Interactions }\end{array}$ & $-0.19(0.22)$ & $-0.05(0.18)$ \\
\hline High-tech * High-tech & $-0.52(0.27)$ * & $-0.62(0.32) * *$ \\
\hline Low-tech * Low-tech & $-0.32(0.33)$ & $-0.22(0.37)$ \\
\hline High-tech * Low-tech & $0.42(0.20) * *$ & $0.58(0.22) * * \star$ \\
\hline Other Variables: & & \\
\hline $\log (\mathrm{emp})$ & $0.52(0.04)^{* \star \star}$ & 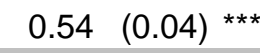 \\
\hline $\log (k)$ & 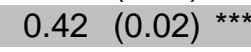 & $0.43(0.02)^{* * \star}$ \\
\hline Size Class2 & $-0.05(0.06)$ & $-0.05(0.06)$ \\
\hline Size Class3 & $0.00(0.07)$ & $-0.01(0.07)$ \\
\hline Size Class4 & $-0.05(0.09)$ & $-0.04(0.09)$ \\
\hline Size Class5 & $0.02(0.13)$ & $-0.06(0.13)$ \\
\hline Spike dummy & $0.04(0.04)$ & $0.06 \quad(0.04)$ \\
\hline Constant & $3.31(0.17)^{\star \star \star \star}$ & $1.86(0.24)^{* \star *}$ \\
\hline $\begin{array}{l}\text { Number of Observations } \\
\text { R-Sq }\end{array}$ & $\begin{array}{l}1651 \\
0.899\end{array}$ & $\begin{array}{r}1502 \\
0.897 \\
\end{array}$ \\
\hline
\end{tabular}

Notes: These regressions also include 3-digit SIC industry dummies and state dummies, though due to confidentiality concerns, the coefficients on these dummies are not shown. "High-tech" consists of Computers, Communications Equipment, Software, Instruments, Electrical Equipment, Metalworking Machinery, Autos, Aerospace, and Special Industry Machinery. "Low-tech" consists of Other Office Equipment, Fabricated Metal Products, Heavy Duty Trucks, Other Transportation Equipment, General Purpose Machinery, Miscellaneous Equipment, and all Structures Types.

Robust standard errors are shown in parentheses. Coefficients on Industry and State dummies not shown.

*** denotes significance at the $99 \%$ level

** denotes significance at the $95 \%$ level

* denotes significance at the $90 \%$ level 
Table 5. Interactions between Capital Types and Labor in 1998 Cross-Section Regression

\begin{tabular}{|c|c|c|c|c|c|}
\hline & \multicolumn{2}{|c|}{ Special Industry Machinery omitted } & \multicolumn{3}{|c|}{ General Purpose Machinery omitted } \\
\hline & $(1)$ & $(2)$ & $(3)$ & \multicolumn{2}{|c|}{$(4)$} \\
\hline & Overall Effect & In(emp) Interaction & Overall Effect & $\ln (\mathrm{emp})$ & Interaction \\
\hline Variable & Coef. Estimate & Coef. Estimate & Coef. Estimate & Coef. & Estimate \\
\hline Aircraft & $-0.13(0.19)$ & $0.06 \quad(0.07)$ & $-0.06 \quad(0.21)$ & -0.09 & $(0.08)$ \\
\hline Autos & $0.36 \quad(0.39)$ & $0.06 \quad(0.08)$ & $0.43 \quad(0.40)$ & -0.08 & $(0.09)$ \\
\hline Commercial Buildings & $0.02 \quad(0.17)$ & $-0.08 \quad(0.06)$ & $0.09 \quad(0.20)$ & -0.22 & $(0.08) * \star \star$ \\
\hline Communications and AV Equipment & $0.65(0.29)$ ** & $0.06 \quad(0.08)$ & $0.72(0.32) \star *$ & -0.09 & $(0.09)$ \\
\hline Computers & $0.49 \quad(0.13) * \star \star$ & $0.02 \quad(0.06)$ & $0.57(0.16) * * *$ & -0.13 & $(0.08)$ * \\
\hline Electrical Equipment & $-0.39(0.21)$ * & $0.12(0.07)$ * & $-0.32(0.23)$ & -0.03 & (0.08) \\
\hline Fabricated Metal Products & $-0.11(0.18)$ & $0.02 \quad(0.08)$ & $-0.03 \quad(0.20)$ & -0.13 & (0.09) \\
\hline General Purpose Machinery & $-0.07 \quad(0.13)$ & $0.15(0.06) * *$ & - & - & - \\
\hline Industrial Buildings & $-0.03 \quad(0.16)$ & $0.10 \quad(0.08)$ & $0.05 \quad(0.18)$ & -0.05 & $(0.08)$ \\
\hline Instruments & $0.05 \quad(0.23)$ & $0.04 \quad(0.13)$ & $0.13 \quad(0.26)$ & -0.11 & $(0.14)$ \\
\hline Metalworking Machinery & $0.03 \quad(0.10)$ & $-0.03 \quad(0.05)$ & $0.19 \quad(0.14)$ & 0.17 & $(0.07) * \star$ \\
\hline Miscellaneous Equipment & $0.02 \quad(0.14)$ & $0.01 \quad(0.06)$ & $0.10 \quad(0.17)$ & -0.14 & $(0.08)$ * \\
\hline Office Equipment & $0.47(0.28)$ * & $-0.11 \quad(0.13)$ & $(0.29)$ * & -0.26 & $(0.14)$ * \\
\hline Offices & $0.75(0.24) * \star \star$ & $-0.17 \quad(0.13)$ & $0.83(0.26) * \star *$ & -0.32 & $(0.14) * \star$ \\
\hline Other Structures & $-0.20 \quad(0.17)$ & $0.14(0.08)$ * & $0.13 \quad(0.19)$ & 0.00 & $(0.09)$ \\
\hline Other Transportation Equipment & $-0.13(0.26)$ & $0.05 \quad(0.10)$ & $-0.06 \quad(0.28)$ & -0.10 & $(0.01) * \star \star$ \\
\hline Software & $1.16(0.32) * \star \star$ & $-0.37(0.19)$ * & $1.23(0.33) * \star \star$ & -0.51 & $(0.19) * \star \star$ \\
\hline Trucks & $-0.42 \quad(0.27)$ & $0.23(0.09)$ *** & $(0.27)$ & 0.09 & $(0.09)$ \\
\hline Utility Structures & $-0.14 \quad(0.23)$ & $-0.06 \quad(0.06)$ & $-0.06 \quad(0.24)$ & -0.21 & $(0.08) * \star \star$ \\
\hline Special Industry Machinery & - & - & $0.07 \quad(0.13)$ & -0.15 & $(0.06)$ \\
\hline$\frac{\text { Other Variables: }}{\text { Log(emp) }}$ & $0.54(0.04) * * \star$ & & $0.68(0.06) * \star *$ & & \\
\hline $\log (K)$ & $0.41 \quad(0.02) * \star \star$ & & $0.42(0.02) * \star \star$ & & \\
\hline Spike dummy & $0.04 \quad(0.03)$ & & $0.04 \quad(0.04)$ & & \\
\hline Constant & $3.38(0.17) * \star \star$ & & $3.30(0.17) * * *$ & & \\
\hline $\begin{array}{l}\text { Number of Observations } \\
\text { R-Sq }\end{array}$ & $\begin{array}{r}16 \\
0.8 \\
\end{array}$ & & & & \\
\hline
\end{tabular}

Robust standard errors are shown in parentheses. Coefficients on state and industry dummies are not shown.

$\star \star \star$ denotes significance at the $99 \%$ level

** denotes significance at the $95 \%$ level

* denotes significance at the $90 \%$ level 